\title{
PENGARUH FAKTOR BUDAYA, SOSIAL, PRIBADI, DAN PSIKOLOGI KONSUMEN TERHADAP KEPUTUSAN \\ PEMBELIAN PADA RESTORAN GADO-GADO BOPLO \\ (Studi Kasus: Restoran Gado-Gado Boplo Panglima Polim Jakarta Selatan)
}

\author{
Agung Suprayitno, Siti Rochaeni, Rahmi Purnomowati
}

\begin{abstract}
ABSTRAK
Tujuan Penelitian untuk mengetahui : (1) karakteristik responden terhadap keputusan pembelian (2)pengaruh faktor budaya terhadap keputusan pembelian konsumen (3) pengaruh faktor sosial terhadap keputusan pembelian konsumen (4) pengaruh faktor pribadi terhadap keputusan pembelian konsumen.(5) pengaruh faktor psikologi terhadap keputusan pembelian konsumen (6) pengaruh faktor budaya, sosial, pribadi, dan psikologi terhadap keputusan pembelian konsumen Hasil penelitian ini yaitu: 1) Karakteristik responden yang melakukan pembelian di Restoran Gado-Gado Boplo sebagian besar adalah laki-laki sudah menikah pada usia dewasa (25-50 tahun). Pekerjaan paling dominan adalah Pegawai Negeri Sipil, sebagian pegawai swasta. Pendidikan terakhir konsumen Gado-Gado Boplo mayoritas sarjana. Alasan konsumen membeli produk dari Restoran Gado-Gado Boplo karena kualitas. 2) Faktor budaya berpengaruh terhadap keputusan pembelian dan memiliki arah positif, dibuktikan dengan koefisien regresi sebesar 0,119, nilai t hitung lebih besar dari t tabel (2,258>1,96), dan nilai signifikansi sebesar 0,026<0,05. 3) Faktor sosial berpengaruh terhadap keputusan pembelian dan memiliki arah positif, dibuktikan dengan koefisien regresi sebesar 0,358, nilai thitung lebih besar dari nilai t tabel $(4,736>1,96)$ dan nilai signifikansi sebesar 0,000<0,05. 4) Faktor pribadi berpengaruh terhadap keputusan pembelian dan memilki arah positif, dibuktikan dengan koefisien regresi sebesar 0,156, nilai t hitung lebih besar dari t tabel (2,301>1,96), dan nilai signifikansi sebesar 0,024<0,05. 5) Faktor psikologi berpengaruh terhadap keputusan pembelian dan memilki arah positif, dibuktikan dengan koefisien regresi sebesar 0,164, nilai t hitung lebih besar dari nilai t tabel (2,747>1,96), dan nilai signifikansi sebesar 0,007 <0,05. 6) Faktor budaya, sosial, pribadi, dan psikologi berpengaruh terhadap keputusan pembelian.
\end{abstract}

Kata kunci : Faktor Budaya, Sosial, Pribadi, Psikologi, Keputusan Pembelian Konsumen, Restoran Gado-Gado Boplo Panglima Polim, Jakarta Selatan 


\begin{abstract}
Objective to determine: (1) the characteristics of the respondent on purchase decisions (2) the influence of cultural factors on consumer purchasing decisions (3) the influence of social factors on consumer purchasing decisions (4) the influence of personal factors on consumer purchasing decisions. (5) The influence of psychological factors on consumer purchasing decisions (6) the influence of cultural, social, personal, and psychology on consumer purchasing decisions the results of this study are: 1) Characteristics of respondents who make purchases in Restaurants Gado-Gado Boplo mostly men are married in adulthood (2550 years). Employment is the most dominant Civil Servants, partly private employees. Last Educational consumers Gado-Gado Boplo majority of scholars. The reason consumers buy products from Gado-Gado Restaurant Boplo for quality. 2) Cultural factors influence the purchase decisions and have a positive direction, as evidenced by a regression coefficient of 0.119, the value of $t$ is greater than t table (2.258>1.96), and the significant value of $0.026<0.05$. 3) Social factors influence the purchase decisions and have a positive direction, as evidenced by a regression coefficient of 0.358, the value of $t$ is greater than t table (4.736> 1.96) and the significant value of $0.000<0.05$. 4) Personal factors influence the purchase decisions and have a positive direction, as evidenced by a regression coefficient of 0.156 , the value of $t$ is greater than t table (2.301> 1.96), and a significance value of $0.024<0.05$. 5) psychological factors influence the purchase decisions and have a positive direction, as evidenced by a regression coefficient of 0.164, the value of $t$ is greater than $t$ table (2.747> 1.96), and the significant value of $0.007<0.05$. 6) factor of cultural, social, personal, and psychological influence on purchase decisions.
\end{abstract}

Keywords: Cultural Factors, Social, Personal, Psychology, Purchase DecisioConsumers, Gado-Gado Restaurant Boplo Polim commander, Jakarta South

\section{PENDAHULUAN}

Gaya hidup masyarakat moderen di kota besar khususnya di Jalan Panglima Polim Jakarta Selatan menginginkan makanan yang siap saji di karenakan mereka tidak memiliki waktu untuk memasak sendiri serta menyiapkan makanan di rumah karena disibukan oleh berbagai macam rutinitas yang padat. Konsumen ditengah kesibukan atau rutinitas yang padat bisa membeli makanan siap saji tidak hanya di restoran, tetapi juga dari food service yang ada seperti supermarket, hypermart, maupun counter makanan yang siap dibawa pulang atau take a way. Konsumen tinggal memilih makanan yang diinginkan, dibawa pulang, maupun dibungkus. Alasan pemilihan makanan siap saji dikarenakan praktis, selain itu biaya yang dikeluarkan untuk membeli makanan siap saji relatif murah (Alamsyah, 2009:12). Salah satu produk atau brand dari makanan siap saji adalah Gado-Gado Boplo. GadoGado Boplo merupakan makanan yang memiliki perpaduan budaya Jawa Tengah dengan DKI Jakarta yang didominasi untuk dapat menghasilkan cita rasa yang khas. Gado-Gado Boplo menjadi salah satu makanan siap saji yang dapat di jadikan 
sebagai alternatif konsumen dalam memenuhi kebutuhan terhadap makanan. Gado-Gado Boplo memilki penyajian yang berbeda dengan gado-gado yang ada pada umumnya. Kacang mete merupakan salah satu saus kacang yang digunakan untuk bumbu pada gado-gado, penyajiannya dengan dibaluri kombinasi yang terdapat pada gado-gado, seperti: bayam, selada air, telor, tempe, tauge, lontong, dan kacang panjang. Selain itu sayuran yang digunakan menggunakan sayur organik, seperti bayam dan selada air. Fitur-fitur seperti kacang mede, sayuran, tempe, tauge, dan telur merupakan salah satu elemen yang dapat menyatu menjadikan sebuah produk atau brand bernama Gado-Gado Boplo dan memberikan rasa khas pada bumbu yang berasal dari kacang mete maupun sayuran organik.

Menurut hasil survei yang dilakukan oleh Nielsen (2008;10) menunjukkan bahwa $85 \%$ masyarakat kota di Indonesia mengkonsumsi makanan di restoran cepat saji, sebesar $28 \%$ yaitu minimal satu kali dalam seminggu. Presentase tersebut semakin meningkat setiap tahunnya karena pergeseran trend masyarakat dalam mengonsumsi makanan di restoran siap saji. Pada kenyataannnya sekarang ini banyak sekali perusahaan yang menghasilkan suatu produk yang sama atau sejenis, berlomba untuk bersaing merebut pasar konsumen. Oleh karena itu, perusahaan harus mampu mengetahui apa yang selama ini menjadi kebutuhan dan keinginan konsumen terhadap suatu produk selain hal-hal menciptakan produk yang berkualitas, pelayanan yang memuaskan, dan merek yang terkenal di pasaran. Banyaknya konsumen yang semakin membutuhkan makanan siap saji menyebabkan para pelaku bisnis membuka restoran untuk memenuhi kebutuhan pangan konsumen.

Dari segi psikologi, menurut Kotler (2005:216), merupakan karakteristik pengenalan terhadap perasaan seseorang, mengumpulkan dan menganalisis terhadap keputusan pembelian. Konsumen yang datang kebanyakan karena merasa lapar, sehingga adanya motivasi konsumen untuk memenuhi kebutuhan biogenik seperti rasa haus, dan lapar. Konsumen mempertimbangkan terlebih dahulu mengenai produk yang terdapat pada restoran, apakah produk tersebut sudah ada atau belum, kebiasaan konsumen dalam membeli biasanya berdasarkan keyakinan mengenai apa yang di beli dan kelebihan apa yang terdapat pada produk tersebut.

Salah satu faktor tersebut dapat memberikan pengaruh lebih dari faktor yang lain. Pola konsumsi masyarakat terhadap suatu produk terbentuk karena pengaruh budaya, sosial, pribadi dan psikologi. Setelah mereka mengetahui produk yang dibutuhkan maka konsumen akan mengambil suatu keputusan apakah membeli atau tidak membeli produk tersebut.

Table 12. Merk dan Presentase Pangsa Pasar Gado-Gado di Menteng Jakarta Pusat Tahun 2014

\begin{tabular}{|l|l|l|}
\hline No & Merk & Presentase \\
\hline 1 & Gado-Gado Boplo & $6,29 \%$ \\
\hline 2 & Gado-Gado Cemara & $4,2 \%$ \\
\hline 3 & Gado-Gado Bonbin & $3,7 \%$ \\
\hline
\end{tabular}

Sumber : www.kulinerart.com. (2014: 10)

Berdasarkan Tabel 1 dapat dilihat mulai banyak bermunculan pesaing baru di industri restoran siap saji gado-gado yang menawarkan produk gado-gado sebagai 
menu utama. Presentase dari Restoran Gado-Gado Boplo lebih tinggi dari pesaingnya dikarenakan restoran ini menjadi salah satu restoran favorit keluarga yang memiliki banyak macam menu yang ditawarkan dibandingkan dengan merk gado-gado lain. Kendala yang dialami oleh pihak manajemen Restoran GadoGado Boplo adalah terdapatnya beberapa saran dan masukan dari konsumen mengenai harga yang ditawarkan Restoran GadoGado Boplo terlalu mahal dibandingkan produk lain. Permasalahan dalam proses keputusan pembelian produk di Restoran Gado-Gado Boplo karena adanya dorongan terhadap kebutuhan rasa lapar serta dorongan bersosialisasi untuk mencoba hal baru atau pencitraan. Permasalahan lain budaya konsumsi masyarakat kian meningkat dikarenakan adanya pengaruh lingkungan yang menyebabkan konsumen terbiasa untuk mengkonsumsi makanan cepat saji, ditinjau dari tingkat keseringan konsumen dalam memenuhi kebutuhan pangan. Perubahan gaya hidup konsumen pada era modern terutama yang memilki jumlah penghasilan tinggi menginginkan makanan yang cepat saji atau praktis guna memenuhi kebutuhan mereka, hal ini disebabkan terjadinya peningkatan terhadap keputusan pembelian.

Banyaknya produk pesaing yang bermunculan dari industri restoran siap saji salah satunya gado-gado mencerminkan gaya hidup yang menyebabkan pola konsumsi masyarakat berubah. Pola konsumsi masyarakat yang berubah serta prospek industri cepat saji yang baik menimbulkan banyak perusahaan muncul dalam menjual makanan cepat saji di Indonesia. Kecenderungan masyarakat perkotaan bahwa makan di restoran siap saji memiliki nilai sosial atau gengsi tersendiri yang mampu meningkatkan status dirinya. Oleh karena itu, untuk mengetahui pengaruh terhadap faktor Budaya, Sosial, Pribadi, dan Psikologi, maka suatu penelitian mengenai "Pengaruh

Faktor Budaya, Sosial, Pribadi, dan Psikologi Konsumen Terhadap Keputusan Pembelian (Studi Kasus : Restoran Gado-Gado Boplo, Panglima Polim, Jakarta Selatan)" perlu dilakukan. Untuk melihat sejauh mana faktor budaya, sosial, pribadi, dan psikologi mampu mempengaruhi konsumen dalam melakukan keputusan pembelian di Restoran Gado-Gado Boplo.

\section{METODE PENELITIAN}

\section{Lokasi dan Waktu Penelitian}

Penelitian ini dilakukan di Restoran Gado-Gado Boplo cabang Panglima Polim IX No.124 Kelurahan Melawai, Kecamatan Kebayoran Baru Jakarta-Selatan. Lokasi ini dipilih secara sengaja (Purposive) dengan pertimbangan bahwa Gado-Gado Boplo merupakan restoran yang menyediakan makanan tradisional dengan nuansa modern dan sayuran yang digunakan organik. Penelitian ini dilaksanakan bulan FebruariApril 2015.

\section{Metode Pengolahan dan Analisis Data}

Metode pengolahan dan analisis data dalam penelitian ini menggunakan regresi linier berganda. Untuk memenuhi persyaratan regresi linier berganda diperlukan pengujian alat instrumen dengan menggunakan 20 responden awal sebagai percobaan (uji coba). Kuisioner yang telah valid dan reliabel disebarkan kepada 100 orang responden untuk mengumpulkan data 
penelitian. Kuisioner yang telah terisi oleh responden dilakukan proses koding, scoring, tabulasi, dan pembobotan. Pembobotan setiap variabel merupakan data penelitian yang perlu dilakukan uji asumsi klasik untuk melihat apakah data yang terkumpul sudah layak berdasarkan uji normalitas, uji multikolinieritas, dan uji heteroskedastisitas.

Data yang sudah layak, dilakukan pengujian dengan menggunakan analisis regresi linier berganda untuk menguji hipotesis yang telah dirumuskan. Regresi digunakan untuk mengetahui pengaruh variabel bebas: Budaya (X1), Sosial (X2),Pribadi (X3), dan Psikologi (X4), terhadap variabel terikat: keputusan pembelian (Y). Pengolahan dan analisis data pada penelitian ini dilakukan ${ }^{+}$ 1 bulan. Hambatan yang dialami dalam proses pengumpulan data, terdapatnya keengganan konsumen untuk mengisi kuisioner, karena mengganggu konsumen dalam menikmati hidangan, solusi dari kendala ini melakukan pendekatan kepada konsumen dengan cara meminta ketersediaan untuk mengisi kuisioner setelah menikmati hidangan di Restoran Gado-Gado Boplo.

Analisis data yang digunakan untuk mengetahui karateristik konsumen dalam pengambilan keputusan pembelian produk gado-gado boplo dengan menggunakan analisis deskriptif yaitu analisis karakteristik responden. Analisis data yang digunakan untuk mengetahui pengaruh faktor budaya, sosial, pribadi, dan psikologi terhadap keputusan pembelian menggunakan analisis regresi linier berganda dengan bantuan statistical package for the social science SPSS versi 18.

\section{Uji Instrumen}

Instrumen penelitian yang berupa kuisioner diuji dengan menggunakan uji validitas dan reabilitas.

\section{Uji validitas}

Uji validitas merupakan derajat ketepatan antara data yang terjadi pada objek penelitian dengan data yang dapat dilaporkan oleh peneliti (Sugiyono,

2012:203). Dalam pengujian validitas untuk setiap butir pertanyaan dalam kuisioner menggunakan analisis item yaitu dengan mengkorelasikan skor tiap butir pertanyaan dengan skor total menggunakan rumus teknik Korelasi Pearson.

Uji validitas digunakan untuk mengukur sah atau valid tidaknya suatu kuisioner. Suatu kuisioner dikatakan valid jika pernyataan pada kuisioner mampu mengungkapkan sesuatu yang akan diukur oleh kuisioner tersebut (Ghozali, 2010:52).

Uji validitas ini menggunakan rumus Pearson Correlation (karena data yang digunakan skala likert 1-5 dengan data interval dan teknik samplingnya random) dan alat bantu SPSS.

Rumus dari teknik uji Validitas ini adalah sebagai berikut

$$
\begin{array}{|l}
\hline \frac{\mathrm{r}=}{\mathrm{n}=\left(\sum \mathrm{XY}\right)-\left(\sum \mathrm{X} \sum \mathrm{Y}\right)} \\
\begin{array}{l}
\text { Dengan keterangan } \\
\text { berikut: }
\end{array} \\
\mathrm{R}=\text { sebagai } \\
\mathrm{X}=\text { koefisien korelasi } \\
\mathrm{N}=\text { jumlah responden } \\
\mathrm{Y}=\text { skor total }
\end{array}
$$


Kriteria yang digunakan untuk menyatakan bahwa data tersebut valid atau tidak adalah sebagai berikut:

1. Jika nilai pearson correlation $>0,3$, di nyatakan butir valid ( $\mathrm{r}_{\text {hitung }}>\mathrm{r}_{\text {tabel }}$ )

2. Jika nilai pearson correlation $<0,3$, di nyatakan butir tidak valid ( $\mathrm{r}$ hitung $<\mathrm{r}_{\text {tabel }}$ )

Hasil uji validitas penelitian menunjukkan hampir semua butir pertanyaan valid. Dari total 35 butir pertanyaan, sebagian besar memiliki nilai koefisien correlation $>0,3$. Dari proses uji validitas terdapat butir variabel yang tidak valid, yaitu: variabel budaya pada butir 1, 2, dan 3 dan variabel psikologi pada butir 1 memiliki nilai koefisien korelasi $<0,3$. Butir pertanyaan yang tidak validdi keluarkan dari kuisioner (didrop). Sedangkan butir pertanyaan variabel yang valid, yaitu: variabel budaya pada butir 4,5,6,7,8,9,10, variabel sosial pada butir

1,2,3,4,5,6, variabel pribadi pada butir $1,2,3,4,5$, variabel psikologi pada butir $2,3,4,5,6,7,8$, dan variabel keputusan pembelian pada butir 1,2,3,4,5,6, memiliki nilai koefesien korelasi $>0,3$. Butir pertanyaan yang valid sebanyak 31 pertanyaan pada kuisioner. Masing-masing butir pertanyaan yang valid selanjutnya dilakukan pengolahan dengan menggunakan analisis regresi linier berganda. Hasil uji validitas dapat dilihat pada Lampiran 3.

\section{Uji Reliabilitas}

Menurut Ghozali (2011:47) uji reliabilitas adalah alat untuk mengukur suatu kuisioner yang merupakan indikator dari variabel atau konstruk. Teknik ini pengukurannya hanya sekali kemudian hasilnya dibandingkan dengan pertanyaan lain atau mengukur korelasi antar jawaban pertanyaan dengan Alpha Cronbach dengan bantuan SPSS.

Rumus dari teknik uji Reliabilitas ini menurut Umar (2003:207) adalah sebagai berikut:

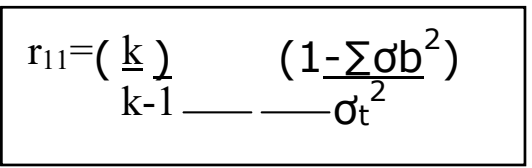

Dengan keterangan sebagai berikut:

$\mathrm{r}_{11} \quad$ : reliabilitas instrumen $\mathrm{k}$ : banyak butir pertanyaan $\mathrm{o}_{\mathrm{t}}^{2}$ : varians total $\sum \mathrm{o}_{\mathrm{b}}^{2}$ : jumlah varians butir Kriteria instrumen dapat dikatakan reliabel, (menurut Ghozali: 2011:48), apabila:

1. Alpha Cronbach $>0,6$ konstruk dikatakan reliabel

2. Alpha Cronbach $<0,6$ konstruk dikatakan tidak reliabel

Proses pengujian validitas dan reliabilitas dengan menggunakan data dari 20 responden awal untuk 35 pertanyaan dalam kuisioner. Hasil uji instrumen terdapat 4 pertanyaan tidak memenuhi uji validitas (reliabilitas) atau keduanya, sehingga yang digunakan untuk mengumpulkan data sebanyak 31 pertanyaan dalam kuisioner.

Penelitian ini menggunakan uji reliabilitas dengan teknik Alpha Cronbach. Hasil uji reliabilitas menunjukan 31 pertanyaan variabel pada instrumen penelitian memiliki nilai Cronbach Alpha $>0,6$ sehingga dapat dikatakan butir pertanyaan reliabel. Menurut siregar (2014:173) 
kriteria suatu instrumen dikatakan reliabel yaitu apabila koefisien reliabilitas $\left(\mathrm{r}_{11}\right)$ bernilai $>0,6$. Hasil uji reliabilitas penelitian ini dapat dilihat pada Lampiran 3

\section{Uji Asumsi Klasik}

1. Uji Normalitas

Pada penelitian ini uji
normalitas menggunakan normal
probability plot atau p-plot. Menurut
Ghozali (2011:160) tujuan uji normalitas adalah ingin mengetahui apakah dalam model regresi variabel pengganggu atau residual memiliki distribusi normal. Model regresi yang baik adalah memilki distribusi data normal atau mendekati normal.

Normal probability plot pada prinsipnya normalitas dapat dideteksi dengan melihat penyebaran data (titik) pada sumbu diagonal atau dari grafik atau dengan melihat histogram residualnya. Dasar pengambilan keputusan:

1. Jika data menyebar di sekitar garis diagonal dan mengikuti arah garis diagonal atau grafik histogramnya menunjukkan pola distribusi normal, maka model regresi memenuhi asumsi normalitas

2. Jika data menyebar jauh dari diagonal dan atau tidak mengikuti arah garis diagonal atau grafik histogram tidak menunjukkan pola distribusi normal, maka model regresi tidak memenuhi asumsi normalitas

Menurut Santoso (2014:190), uji normalitas dilakukan untuk mengetahui apakah dalam sebuah model regresi nilai residu dari regresi mempunyai distribusi yang normal. Asumsi normalitas dapat dilihat dari tampilan p-plot.

2. Uji Multikolinieritas

Uji ini bertujuan untuk menguji apakah pada model regresi ditemukan adanya korelasi diantara variabel independen. Model regresi yang baik seharusnya tidak terjadi korelasi diantara variabel independen karena akan mengurangi keyakinan dalam pengujian signifikansi.

Untuk mendeteksi ada atau tidaknya gejala multikolinieritas didalam model regresi ini dengan melihat nilai Variance Inflation Factor (VIF), nilai cutoff yang umum dipakai untuk menunjukkan adanya multikolinieritas adalah nilai VIF $>10$. Dasar pengambilan keputusan, apabila nilai VIF $>10$, maka terjadi multikolinieritas, sebaliknya apabila nilai VIF $<10$ dan tolerance mendekati 1, maka tidak terjadi multikolinieritas (Sarjono, 2011:70).

\section{Uji Heteroskedastisitas}

Uji ini bertujuan untuk melihat apakah dalam model regresi terjadi ketidaksamaan variabel dari residual satu pengamatan ke pengamatan yang lain. Jika varian dari residual satu pengamatan ke pengamatan lain tetap, maka disebut homoskedastisitas, dan jika berbeda disebut heteroskedastisitas.

$\begin{array}{llr}\text { Model } & \text { regresi yang baik } \\ \text { adalah } & \text { tidak terjadi } \\ \text { heteroskedastisitas. Dalam penelitian } \\ \text { ini Uji heterokedastisitas dilakukan } \\ \text { dengan cara melihat grafik scatter plot }\end{array}$


antar prediksi variabel dependen (ZPRED) dengan residualnya (SRESID). Uji heterokedastisitas dengan grafik scatter plot pada prinsipnya dilakukan dengan cara melihat antar prediksi variabel dependen (ZPRED) dengan residualnya (SRESID). Menurut (Ghozali, 2011:139), dasar analisis heteroskedastisitas sebagai berikut:

1. Jika ada pola yang jelas, seperti titiktitik yang ada membentuk pola tertentu yang teratur, maka terjadi heteroskedaktisitas,

2. Jika tidak ada pola yang jelas, seperti titik-titik menyebar di atas dan di bawah angka nol pada sumbu Y, maka tidak terjadi hetroskedastisitas atau homoskedaktisitas

\section{Analisis Regresi Linear Berganda}

Analisis regresi berganda dalam penelitian ini bertujuan untuk mengetahui besarnya pengaruh variabel independen terhadap variabel dependen. Adapun bentuk umum persamaan regresi berganda yang digunakan dalam penelitian ini sebagai berikut :

$\mathrm{Y}=\mathrm{a}+\mathrm{b}_{1} \mathrm{X}_{1}+\mathrm{b}_{2} \mathrm{X}_{2}+\mathrm{b}_{3} \mathrm{X}_{3}+\mathrm{b}_{4} \mathrm{X}_{4}+\mathrm{e}$

Di mana :

$\begin{array}{ll}\mathrm{Y} & =\text { Keputusan pembelian } \\ \mathrm{X}_{1} & =\text { Budaya } \\ \mathrm{X} 2 & =\quad \text { Sosial } \\ \mathrm{X} 3 & =\text { Pribadi } \\ \mathrm{X} 4 & =\text { Psikologi }\end{array}$

$\begin{array}{ll}\mathrm{a} & =\text { Koefisien konstanta } \\ \mathrm{b} 1-\mathrm{b} 4 & =\text { Koefisien independen } \\ & \text { variabel }=\text { parameter } \\ \mathrm{e} & =\text { Standar error atau error } \\ & \text { term }\end{array}$

Untuk dapat menduga besaran koefisien regresi atau parameter masingmasing variabel dilakukan uji statistik. Ketetapan fungsi dari model persamaan regresi keputusan pembelian Gado-Gado Boplo dalam menaksir nilai dugaan parameter dapat diukur dengan Uji t,Uji F,dan Uji $\mathrm{R}^{2}$ atau nilai koefisien determinasi.

\section{Uji Hipotesis}

\section{Uji- t (Pengujian Parameter Regresi Secara parsial)}

Uji $\mathrm{t}$ digunakan untuk menunjukkan seberapa jauh pengaruh satu variabel penjelas atau independen secara individual dalam menerangkan variasi variabel dependen. Uji ini digunakan untuk menguji signifikansi hubungan antara variabel

$\mathrm{X}$ dan Y. Apakah variabel budaya (X1), sosial (X2), pribadi (X3) dan psikologi

(X4) benar-benar berpengaruh terhadap variabel keputusan pembelian konsumen (Y) secara terpisah atau parsial. Uji ini dilakukan dengan membandingkan $t$ hitung dengan $\mathrm{t}$ tabel. Kriteria pengujian dengan tingkat signifikansi $(\alpha)=0,05$. 


Untuk mengkaji pengaruh
variabel independen terhadap
dependen secara individu dapat
dilihat hipotesis berikut:

1. $\mathrm{H}_{0}$ : Tidak terdapat pengaruh antara faktor budaya, sosial, pribadi, dan psikologi konsumen terhadap keputusan pembelian .

2. $\mathrm{H}_{1}$ : Terdapat pengaruh antara faktor budaya, sosial, pribadi, dan psikologi konsumen terhadap keputusan pembelian .

Kriteria Uji :

$\mathrm{H}_{0}$ ditolak apabila : Thitung $>\mathrm{T}_{\text {tabel, }}$ derajat bebas tertentu( $\mathrm{H}_{1}$ diterima), atau (variabel bebas / independen dalam model berpengaruh nyata terhadap variabel terikat / dependen)

$\mathrm{H}_{0}$ diterima apabila : $\mathrm{T}_{\text {hitung }}<\mathrm{T}_{\text {tabel }}$, derajat bebas tertentu ( $\mathrm{H}_{1}$ ditolak), atau (variabel bebas /independen dalam model tidak berpengaruh nyata terhadap variabel terikat/dependen)

Rumus $\mathrm{t}$ hitung yaitu:

$$
t_{\text {hitung }}=\frac{r \sqrt{n^{-2}}}{\sqrt{1-r^{2}}}
$$

Keterangan $: \mathrm{t}=$ tingkat signifikan

$$
\begin{gathered}
\mathrm{r}=\text { nilai koefisien regresi } \\
\mathrm{n}=\text { jumlah sampel }
\end{gathered}
$$

\section{Uji- F (Pengujian SerentakSeluruh} Parameter Dugaan)

Uji F menunjukkan apakah semua variabel independen yang dimasukkan ke dalam model regresi mempunyai pengaruh secara bersama-sama terhadap variabel dependen (Ghozali, 2011:98).

Pada uji $\mathrm{F}$ jika tingkat signifikansi lebih kecil dari 0,05 maka dapat dinyatakan bahwa variabel independen secara simultan atau bersama-sama mempengaruhi variabel dependen (untuk tingkat signifikansi $=5 \%$ ), maka variabel independen secara serentak berpengaruh terhadap variabel dependen. Sedangkan jika nilai probabilitas lebih besar dari 0,05 maka variabel independen secara serentak tidak berpengaruh terhadap variabel dependen. Kaidah pengujian signifikansi:

Jika $F_{\text {hitung }}>\mathrm{F}_{\text {tabel }}$, pada taraf nyata $\alpha$ : tolak $\mathrm{H}_{0}$ (secara bersama-sama variabel yang digunakan berpengaruh nyata terhadap parameter dependen yaitu Y)

Jika $\mathrm{F}_{\text {hitung }}<\mathrm{F}_{\text {tabel, }}$ pada taraf nyata $\alpha$ : terima $\mathrm{H}_{0}$ (secara bersama-sama variabel yang digunakan tidak berpengaruh nyata terhadap parameter dependen yaitu Y)

Rumus uji F hitung yaitu:

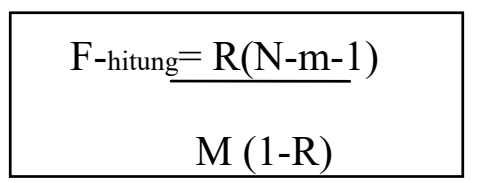
Keterangan : $\mathrm{N}=$ banyak data $\mathrm{m}=$ jumlah variabel independen

\section{Uji - $\mathbf{R}^{2}$ ( Koefisien Determinasi)}

Uji $\mathrm{R}^{2}$ digunakan untuk melihat seberapa besar variabel yang dimasukkan ke dalam model dapat menerangkan model. Secara verbal $\mathrm{R}^{2}$ merupakan 
besaran yang paling sering digunakan untuk mengukur goodness of fit (kesesuaian model) garis regresi. Ghozali (2011:97) berpendapat bahwa koefisien determinasi $\left(\mathrm{R}^{2}\right)$ pada intinya mengukur seberapa jauh kemampuan model dalam menerangkan variasi variabel dependen. Koefisien determinasi digunakan agar mengetahui kuatnya pengaruh dari seluruh variabel independen: budaya (X1), sosial (X2), pribadi (X3), dan psikologi (X4) terhadap variabel dependen: keputusan pembelian (Y).

Semakin tinggi nilai koefisien determinasi $\left(\mathrm{R}^{2}\right)$ berarti model dugaan yang diperoleh semakin akurat untuk meramal variabel dependen. Sebaliknya, jika semakin rendah atau mendekati 0 , maka variabel independen secara keseluruhan tidak dapat menjelaskan variabel dependen. Untuk mengukur kemampuan variabel independen dalam menjelaskan keragaman variabel dependen yang diteliti. $\mathrm{R}^{2}$ memiliki range antara $0 \geq \mathrm{R}^{2} \leq 1$. Apabila $\mathrm{R}^{2}$ bernilai 1 maka garis regresi menjelaskan $100 \%$ variasi dalam variabel dependen. Sedangkan jika $\mathrm{R}^{2}$ bernilai 0 maka garis regresi tidak menjelaskan variasi variabel dependen. Semakin besar nilai $\mathrm{R}^{2}$, maka semakin baik model regresi yang diperoleh (Widarjono, 2007:71). Rumus yang digunakan adalah:

\begin{tabular}{|l|l|}
\hline $\begin{array}{l}\text { KD }=R^{2} x \\
100 \%\end{array}$ \\
\hline$<0,10$ & $\begin{array}{l}\text { Buruk } \\
\text { ketepatanya }\end{array}$ \\
\hline
\end{tabular}

\begin{tabular}{|l|l|}
\hline $\begin{array}{l}\text { 0,11- } \\
0,30\end{array}$ & $\begin{array}{l}\text { Rendah } \\
\text { ketepatanya }\end{array}$ \\
\hline $\begin{array}{l}0,31- \\
0,50\end{array}$ & $\begin{array}{l}\text { Cukup } \\
\text { ketepatanya }\end{array}$ \\
\hline$>0,50$ & $\begin{array}{l}\text { Tinggi } \\
\text { ketepatamya }\end{array}$ \\
\hline & \\
\hline
\end{tabular}

\section{HASIL DAN PEMBAHASAN}

\section{Karakteristik Responden}

Responden dalam penelitian ini berjumlah 100 orang. Responden tersebut merupakan konsumen dari Restoran GadoGado Boplo. Penulis melakukan penyebaran kuisioner pada jam makan siang (pukul 13.00 - 15.00). Responden diminta kesediaan untuk mengisi angket yang telah disediakan. Karakteristik umum responden dalam penelitian ini terbagi atas Identitas Responden dan Pendapat atau Persepsi Konsumen. Identitas Responden terdiri atas: usia, jenis kelamin, status pernikahan, pendidikan terakhir, besar pengeluaran dalam sebulan, jenis pekerjaan, lama bekerja, alasan membeli produk dari Restoran Gado-Gado Boplo, menu yang sering dipesan maupun dipilih saat pembelian, dan kepuasan konsumen terhadap Restoran Gado-Gado Boplo. Sedangkan Pendapat atau Persepsi Konsumen terdiri atas hal-hal yang berkaitan dengan faktor budaya, sosial, pribadi dan psikologi responden. Identitas responden akan dibahas lebih rinci seperti berikut ini :

\section{Usia}

Usia dapat mempengaruhi selera seseorang dalam mengkonsumsi suatu makanan. Orang akan mengubah barang 
dan jasa yang mereka beli sepanjang kehidupan mereka. Kebutuhan dan selera seseorang akan berubah sesuai dengan usia. Pembelian dibentuk oleh tahap daur hidup keluarga, sehingga pemasar hendaknya memperhatikan minat pembelian yang terjadi yang berhubungan dengan daur hidup manusia (Simamora, 2004:145). Ditinjau dari aspek usia karakteristik konsumen Restoran Gado-Gado Boplo dapat dilihat pada Tabel 3

berikut.

Tabel 3. Identitas Responden Berdasarkan Usia di Restoran Gado-Gado Boplo

Panglima Polim tahun 2015

\begin{tabular}{|l|l|l|l|}
\hline No & Usia & Jumlah & Presentase (\%) \\
\hline 1 & $18-24$ & 14 & 14 \\
2 & $25-50$ & 86 & 86 \\
\hline & Jumlah & 100 & 100 \\
\hline
\end{tabular}

Sumber: data primer (diolah)

Dari Tabel 3 dapat diketahui karakteristik responden dilihat dari usia. Pada Tabel diatas, diketahui bahwa sebanyak 86 responden berumur 25-50 tahun dengan presentase $86 \%, 14$ responden berumur 18-24 tahun dengan presentase $14 \%$, dari total responden 100 orang dengan presentase kumulatifnya $100 \%$. Hal ini berarti konsumen dari restoran Gado-Gado Boplo didominasi oleh usia dewasa pada kisaran 25-50 tahun dimana sebagian besar respoden pada usia tersebut lebih cenderung memikirkan memilih makanan yang sehat untuk dikonsumsi.

Pada usia dewasa pola berpikir lebih matang dibandingkan dengan usia remaja terutama dalam memilih menu makanan. Biasanya usia dewasa lebih cenderung berpikir pola hidup sehat yaitu dengan memilih konsumsi makanan serba sayuran (vegetarian). Sedangkan untuk usia remaja mereka lebih menyukai makanan yang serba instant tanpa memikirkan pola hidup sehat. Usia remaja cenderung mencari hiburan serta lebih mengikuti gaya hidup modern. Banyaknya usia 25-50 tahun yang datang disebabkan karena usia tersebut merupakan usia produktif. Mereka lebih cenderung bersosialisasi dengan rekannya, mencoba hal baru, dan relatif mudah terpengaruh oleh ajakan teman, biasanya lebih sering pergi bersama keluarga (relasi).

Sesuai teori yang dikemukakan oleh Kotler (2005:213), usia akan mendorong terjadinya perubahan jenis makanan yang dikonsumsinya sehubungan dengan kecenderungan mencari makanan yang sehat untuk menunjang aktifitasnya seharihari, disamping pemenuhan gaya hidup ialah menjalin komunikasi dengan relasi, dan sebagai investasi di hari tuanya.

\section{Jenis Kelamin}

Ditinjau dari aspek jenis kelamin karakteristik konsumen Restoran Gado-

Gado Boplo dapat dilihat pada Tabel 4 berikut.

Tabel 4. Identitas Responden Berdasarkan Jenis Kelamin di Restoran Gado-

Gado Boplo Panglima Polim tahun 2015

\begin{tabular}{|c|c|c|c|}
\hline No. & $\begin{array}{l}\text { Jenis } \\
\text { Kelamin }\end{array}$ & Jumlah & $\begin{array}{l}\text { Presentase } \\
(\%)\end{array}$ \\
\hline \multirow[t]{2}{*}{1} & \multirow{2}{*}{$\begin{array}{l}\text { Laki-laki } \\
\text { Perempuan }\end{array}$} & 52 & 52 \\
\hline & & 48 & 48 \\
\hline & Jumlah & 100 & 100 \\
\hline
\end{tabular}

Sumber : data primer (diolah) 
Dari Tabel 4 dapat diketahui karakteristik konsumen dilihat dari jenis kelamin responden. Pada Tabel diatas, diketahui bahwa sebanyak 52 responden berjenis kelamin laki-laki dengan presentase $52 \%$ dari 100 responden. Sedangkan sebanyak 48 responden berjenis kelamin wanita dengan presentase $48 \%$ dari 100 responden dengan presentase kumulatifnya $100 \%$. Hal ini disebabkan karena lakilaki memiliki aktivitas pekerjaan diluar rumah maupun rutinitas kerja yang padat, dan mobilitas yang tinggi sehingga dalam memenuhi kebutuhan pangan lebih memilih makanan cepat saji yang praktis.

Berdasarkan pola konsumsi baik laki-laki dan perempuan memiliki keinginan untuk memilih konsumsi pangan. Pemilihan terhadap pangan merupakan salah satu cara dalam menerapkan pola hidup sehat dengan mengkonsumsi makanan yang sehat. Salah satunya yang terdapat di Restoran

Gado-Gado Boplo.

\subsubsection{Status Pernikahan}

Ditinjau dari aspek status pernikahan karakteristik konsumen Restoran

Gado-Gado Boplo dapat dilihat pada Tabel 5 berikut.

Tabel 5. Identitas Responden Berdasarkan Status Pernikahan di Restoran GadoGado Boplo Panglima Polim tahun 2015

\begin{tabular}{|l|l|l|l|}
\hline No. & $\begin{array}{l}\text { Status } \\
\text { Pernikahan }\end{array}$ & Jumlah & $\begin{array}{l}\text { Presentase } \\
(\%)\end{array}$ \\
\hline 1 & Menikah & 73 & 73 \\
2 & $\begin{array}{l}\text { Belum } \\
\text { Menikah }\end{array}$ & 26 & 26 \\
3 & $\begin{array}{l}\text { Janda/Duda } \\
1\end{array}$ & 1 \\
\hline
\end{tabular}

\begin{tabular}{|c|l|l|}
\hline Jumlah & 100 & 100 \\
\hline
\end{tabular}

Sumber : data primer (diolah)

Dari Tabel 5 dapat diketahui karakteristik responden dilihat dari status pernikahan. Pada Tabel diatas, diketahui bahwa sebanyak 73 responden berstatus menikah dengan presentase 73\%, 26 responden berstatus belum menikah dengan presentase $26 \%, 1$ responden berstatus janda dengan presentase $1 \%$ dari 100 responden dengan presentase kumulatifnya $100 \%$. Hal ini berarti sebagian besar konsumen Restoran Gado-Gado Boplo berstatus sudah menikah pada usia dewasa.

Sebagian besar konsumen yang sudah menikah umumnya lebih banyak beraktivitas diluar rumah karena bekerja. Mereka umumnya berkantor di sekitar

Restoran Gado-Gado Boplo. Aktivitas pekerjaan yang padat membuat mereka memiliki waktu terbatas sehingga untuk memenuhi kebutuhan pangan pada jam makan siang mereka melakukan pembelian di Restoran Gado-Gado Boplo tersebut. Selain itu pada hari weekend biasanya konsumen datang bersama keluarganya untuk memanfaatkan waktu kumpul bersama.

Menurut Kotler (2005;210) keluarga mempunyai pengaruh langsung dalam pembelian konsumen. Karena setiap individu dalam keluargTingkat Pendidikan Terakhir

Ditinjau dari aspek Tingkat Pendidikan Terakhir karakteristik konsumen

Restoran Gado-Gado Boplo dapat dilihat pada Tabel 6 berikut. 
Tabel 6. Identitas Responden Berdasarkan Tingkat Pendidikan Terakhir di Restoran Gado-Gado Boplo Panglima Polim tahun 2015

\begin{tabular}{|l|l|l|l|}
\hline No & $\begin{array}{l}\text { Tingkat } \\
\text { Pendidikan }\end{array}$ & Jumlah & $\begin{array}{l}\text { Presentase } \\
(\%)\end{array}$ \\
\hline 1 & SMP & 0 & 0 \\
2 & SMA & 17 & 17 \\
3 & D3 & 18 & 18 \\
4 & S1 & 39 & 39 \\
5 & S2 & 24 & 24 \\
6 & Lainnya & 2 & 2 \\
\hline & Jumlah & 100 & 100 \\
\hline
\end{tabular}

Sumber: data primer (diolah)

Dari Tabel 6 dapat diketahui karakteristik responden dilihat dari Tingkat

Pendidikan Terakhir. Tingkat Pendidikan Terakhir konsumen Restoran GadoGado Boplo cukup bervariasi mulai dari SMA hingga Pasca Sarjana. Pada Tabel diatas, diketahui bahwa sebanyak 39 responden berpendidikan Strata (S1) dengan presentase $39 \%, \quad 24$ responden berpendidikan Strata 2 (S2) dengan presentase

24\%, 18 responden berpendidikan Diploma dengan presentase $18 \%, 17$ responden berpendidikan SMA dengan presentase $17 \%$, dan 2 responden berpendidikan lainnya dengan presentase $2 \%$ dari 100 responden dengan presentase kumulatifnya $100 \%$. Hal ini berarti sebagian besar konsumen dari Restoran GadoGado Boplo berpendidikan cukup tinggi hampir rata-rata konsumen Restoran Gado-Gado Boplo menempuh pendidikan hingga pasca sarjana.
Tingkat pendidikan seseorang akan berpengaruh terhadap pola konsumsinya. Konsumen yang berpendidikan tinggi cenderung berperilaku lebih kritis dan berhati-hati dalam mengkonsumsi pangan. Biasanya mereka mencari informasi terlebih dahulu sebelum melakukan pembelian. Konsumen yang berpendidikan akan lebih memperhatikan kualitas pangan, nilai gizi, kebersihan, dan pelayanan yang diberikan.

Pendidikan akan mempengaruhi kemampuan logika berpikir untuk menemukenali kebutuhan pribadi secara tepat, dan berhubungan dengan kemampuan untuk memilih dan mencari ketepatan dalam menentukan alternatif,

(Kotler, 2005; 211).

\section{Besar Pengeluaran dalam Sebulan}

Ditinjau dari aspek besar pengeluaran dalam sebulan karakteristik konsumen Restoran Gado-Gado Boplo dapat dilihat pada Tabel 7 berikut.

Tabel 7. Identitas Responden Berdasarkan Besar Pengeluaran dalam Sebulan di

Restoran Gado-Gado Boplo Panglima Polim tahun 2015

\begin{tabular}{|c|c|c|c|}
\hline No & $\begin{array}{l}\text { Pengeluaran } \\
\text { (Rp) }\end{array}$ & Jumlah & $\begin{array}{l}\text { Presentase } \\
(\%)\end{array}$ \\
\hline 1 & $<2.700 .000$ & 13 & 13 \\
\hline 2 & $\begin{array}{l}2.700 .000- \\
6.000 .000\end{array}$ & 27 & 27 \\
\hline 3 & $\begin{array}{l}6.000 .000- \\
13.000 .000\end{array}$ & 28 & 28 \\
\hline 4 & $\begin{array}{l}13.000 .000- \\
20.000 .000\end{array}$ & 11 & 11 \\
\hline 5 & $>20.000 .000$ & 21 & 21 \\
\hline & Jumlah & 100 & 100 \\
\hline
\end{tabular}

Sumber: data primer (diolah)

Dari Tabel 7 dapat diketahui karakteristik responden dilihat dari besar 
pengeluaran dalam sebulan. Pada tabel di atas, diketahui bahwa 28 responden memiliki jumlah pengeluaran $\operatorname{Rp} 6.000 .000$ - 13.000.000 dengan persentase 28\%, 27 responden memiliki jumlah pengeluaran $\mathrm{Rp}$ $2.700 .000-6.000 .000$ dengan persentase $27 \%, 21$ responden memiliki jumlah pengeluaran $>$ Rp 20.000.000 dengan persentase $21 \%, 13$ responden memiliki jumlah pengeluaran $<\operatorname{Rp} 2.700 .000$ dengan persentase $13 \%$, dan 11 responden memiliki jumlah pengeluaran $\mathrm{Rp} 13.000 .000$ 20.000 .000 dengan persentase $11 \%$ dari 100 responden dengan persentase kumulatif $100 \%$. Hal ini berarti konsumen dari Restoran Gado-Gado Boplo merupakan konsumen kalangan menengah atas.

Sebagian besar pengeluaran konsumen Restoran Gado-Gado Boplo dalam sebulan berkisar Rp 10.000.000. Penghasilan sebesar ini menunjukkan responden merupakan karyawan yang memiliki posisi menengah di tempat kerjanya. Penghasilan yang dimiliki cukup untuk memenuhi kebutuhan hidup dasar dan memenuhi kebutuhan gaya hidup di kota besar. Dalam hal pilihan makanan gadogado mereka lebih memilih Restoran Gado-Gado Boplo dari pada makanan sejenis di tempat lain. Menurut Kotler (2005; 215) pengeluaran seseorang akan berpengaruh dalam melakukan pembelian. Semakin besar pengeluaran akan berpengaruh terhadap menentukan alternatif selera mengkonsumsi dan pemenuhan kualitas makanan (Sukirno 2005; 81).

\section{Jenis Pekerjaan}

Mata pencarian atau pekerjaan yang dilakukan oleh seseorang dapat mempengaruhi pola konsumsi. Pekerjaan seseorang berkaitan dengan penghasilan yang diperoleh oleh seseorang dan berpengaruh terhadap kemampuan dalam mengkonsumsi sebuah produk. Ditinjau dari aspek jenis pekerjaan karakteristik konsumen Restoran Gado-Gado Boplo dapat dilihat pada Tabel 8 berikut.

Tabel 8. Identitas Responden Berdasarkan Jenis Pekerjaan di Restoran Gado-

Gado Boplo Panglima Polim tahun 2015

\begin{tabular}{|c|c|c|c|}
\hline No & $\begin{array}{l}\text { Jenis } \\
\text { Pekerjaan }\end{array}$ & Jumlah & $\begin{array}{l}\text { Presentase } \\
(\%)\end{array}$ \\
\hline 1 & Pelajar/ & 8 & 8 \\
\hline 2 & $\begin{array}{l}\text { Mahasiswa } \\
\text { Ibu Rumah } \\
\text { Tangga }\end{array}$ & 10 & 10 \\
\hline 3 & Wiraswasta & 11 & 11 \\
\hline 4 & $\begin{array}{l}\text { Pegawai } \\
\text { Negeri Sipil }\end{array}$ & 47 & 47 \\
\hline 5 & $\begin{array}{l}\text { Pegawai } \\
\text { Swasta }\end{array}$ & 14 & 14 \\
\hline 6 & Lainnya & 10 & 10 \\
\hline & Jumlah & 100 & 100 \\
\hline
\end{tabular}

Sumber: data primer (diolah)

Dari Tabel 8 dapat diketahui karakteristik responden dilihat dari jenis pekerjaan. Pada tabel di atas, diketahui bahwa sebanyak 47 responden bekerja sebagai pegawai negeri sipil dengan persentase $47 \%$, 14 responden bekerja sebagai pegawai swasta dengan persentase $14 \%, \quad 11$ responden bekerja sebagai wiraswasta dengan persentase $11 \%, 10$ responden bekerja sebagai ibu rumah tangga dengan presentase $10 \%, 10$ responden lainnya bekerja sebagai dosen dan wirausaha dengan persentase $10 \%$, dan 8 responden bekerja sebagai pelajar atau mahasiswa dengan presentase $8 \%$ dari 100 responden dengan persentase kumulatifnya $100 \%$. Hal ini berarti konsumen Restoran Gado-Gado Boplo 
didominasi bekerja sebagai pegawai negeri sipil.

Letak Restoran Gado-Gado Boplo yang strategis didekat area perkantoran baik negeri maupun swasta, sehingga mayoritas konsumen yang berkunjung ke

Restoran Gado-Gado Boplo memiliki jenis pekerjaan sebagai pegawai negeri, dan swasta karena letak kantornya berada tidak jauh dari restoran. Pekerjaan seseorang mempengaruhi pola konsumsi (Kotler 2005;214). Selain dekat dengan area perkantoran letak strategis dari Restoran Gado-Gado Boplo berada tidak terlalu jauh dengan kampus (sekolahan), perumahan (pemukiman penduduk), tempat usaha (pusat bisnis). Akses Restoran berada pada jalan utama (protokol), sehingga memudahkan konsumen untuk mengunjungi Restoran Gado-Gado Boplo.

\section{Lama Bekerja}

Ditinjau dari aspek identitas responden berdasarkan lama bekerja karakteristik konsumen Restoran GadoGado Boplo dapat dilihat pada Tabel 9

berikut.

Tabel 9. Identitas Responden Berdasarkan Lama Bekerja di Restoran GadoGado Boplo Panglima Polim tahun 2015

\begin{tabular}{|c|c|c|c|}
\hline No & $\begin{array}{l}\text { Lama } \\
\text { Bekerja }\end{array}$ & Jumlah & $\begin{array}{l}\text { Presentase } \\
(\%)\end{array}$ \\
\hline 1 & $<3$ tahun & 28 & 28 \\
\hline 2 & $\begin{array}{l}3-10 \\
\text { tahun }\end{array}$ & 29 & 29 \\
\hline 3 & $\begin{array}{l}10-17 \\
\text { tahun }\end{array}$ & 18 & 18 \\
\hline 4 & $>17$ tahun & 25 & 25 \\
\hline & Jumlah & 100 & 100 \\
\hline
\end{tabular}

Sumber: data primer (diolah)
Dari Tabel 9 dapat diketahui karakteristik responden dilihat dari lama bekerja. Pada tabel di atas, diketahui bahwa 29 responden memiliki lama bekerja 3-10 tahun dengan persentase $29 \%, 28$ responden memiliki lama bekerja $<3$ tahun dengan persentase $28 \%, 25$ responden memiliki lama bekerja $>17$ tahun dengan persentase 25\%, dan 18 responden memilki lama bekerja 10-17 tahun dengan presentase 18\% dari 100 responden dengan persentase kumulatif $100 \%$. Hal ini berarti konsumen Restoran Gado-Gado Boplo memiliki waktu bekerja yang relatif lama. Prinsip dan motivasi seseorang untuk bekerja memiliki perbedaan antara orang satu dengan yang lain. Lama waktu bekerja tergantung dari masing-masing individu dalam menempatkan diri sesuai dengan karakter kepribadian yang

dimiliki.

Lama bekerja seseorang pada satu pekerjaan sangat berpengaruh terhadap pengalaman kerja dan menambah pemenuhan kebutuhan hidup, melalui peningkatan penghasilan diantaranya perubahan terhadap gaya hidup konsumen dalam pembelian salah satunya kebutuhan pangan. Jika seseorang tidak mampu untuk bertahan dalam lingkup pekerjaan, maka tidak mampu untuk memenuhi kebutuhan pangan.

\section{Alasan Membeli Produk Makanan Di Restoran Gado-Gado Boplo}

Ditinjau dari aspek alasan membeli produk di Restoran Gado-Gado Boplo karakteristik konsumen Restoran GadoGado Boplo dapat dilihat pada Tabel 10 berikut. 
Tabel 10. Identitas Responden Berdasarkan Alasan Membeli Produk Makanan di

Restoran Gado- Gado Boplo

Panglima Polim tahun 2015

\begin{tabular}{|l|l|l|l|}
\hline No & \multicolumn{1}{|c|}{$\begin{array}{c}\text { Alasan } \\
\text { membeli } \\
\text { produk } \\
\text { makanan di } \\
\text { Restoran gado- } \\
\text { gado boplo }\end{array}$} & Jumlah & $\begin{array}{c}\text { Presentase } \\
(\%)\end{array}$ \\
\hline 1 & $\begin{array}{l}\text { Kualitas } \\
\text { Produk } \\
\text { Promosi } \\
\text { Harga } \\
\text { Terjangkau } \\
\text { Lokasi } \\
\text { Strategis } \\
\text { Kebutuhan } \\
\text { sehari-sehari } \\
\text { dan gaya } \\
\text { hidup } \\
\text { Lainnya }\end{array}$ & 57 & 57 \\
\hline & 12 & 12 \\
\hline
\end{tabular}

Sumber: data primer (diolah)

Dari Tabel 10 dapat diketahui alasan responden membeli produk makanan di Restoran Gado-Gado Boplo. Pada tabel di atas, diketahui bahwa 57 responden memilih membeli produk makanan di Restoran Gado-Gado Boplo karena kualitas produknya dengan persentase 57\%, 13 responden memilih membeli produk makanan di Restoran Gado-Gado Boplo karena lokasinya strategis dengan persentase $13 \%, 12$ responden memilih membeli produk makanan di Restoran Gado-Gado Boplo karena harganya terjangkau dengan persentase 12\%, 7 responden memilih membeli produk makanan di Restoran gado-gado boplo karena kebutuhan sehari-hari dan gaya hidup dengan persentase 7\%, 6 reponden memilih membeli produk makanan di Restoran Gado-Gado Boplo karena lainnya yaitu menu makanan yang ditawarkan banyak dan makanan yang disajikan tradisional dengan persentase $6 \%$, dan 5 responden memilih membeli produk makanan di Restoran Gado-Gado Boplo karena promosi dengan persentase 5\%. Hal ini berarti konsumen membeli produk makanan di Restoran Gado-Gado Boplo dikarenakan kualitas produk dan lokasinya strategis.

Setelah mendapatkan informasi mengenai alternatif tempat makan, konsumen akan mencari alasan membeli produk makanan serta informasi lebih mengenai hal yang berhubungan dengan restoran tersebut. Kualitas Produk merupakan salah satu alasan konsumen membeli produk dari Gado-Gado Boplo yaitu sebesar 57 persen konsumen (57 orang), dikarenakan Restoran Gado-Gado Boplo menggunakan sayuran organik pada setiap menu yang ditawarkan, salah satunya gado-gado, dan sebanyak 13 persen konsumen (13 orang) menganggap bahwa lokasi restoran merupakan salah satu alasan konsumen membeli produk dari Gado-Gado Boplo, dikarenakan Restoran Gado-Gado Boplo memiliki letak yang sangat strategis karena berada tidak jauh dengan pusat perkantoran dan perumahan, sehingga banyak konsumen yang memilih Restoran Gado-Gado Boplo sebagai salah satu tempat makan, selain itu akses restoran berada pada jalan utama, sehingga memudahkan para konsumen untuk berkunjung ke Restoran Gado-Gado Boplo.

Jarak tempuh dari Restoran GadoGado Boplo ke tempat tinggal konsumen 
sekitar ${ }^{+} 5 \mathrm{~km}$, sedangkan Jarak tempuh dari Restoran Gado-Gado Boplo ke tempat kerja konsumen ${ }_{-}^{+} 1-3 \mathrm{~km}$. Konsumen berkunjung ke Restoran Gado-gado Boplo bersama dengan keluarga atau relasi. Jumlah anggota keluarga (relasi) yang biasa ikut berkunjung ke Restoran Gado-gado Boplo adalah sebanyak $1-3$ orang.

Pendapat atau Persepsi Konsumen adalah sebagai berikut : sebanyak 61 orang (61 persen) konsumen memperoleh informasi mengenai Restoran GadoGado Boplo yang beralamat di Jalan Panglima Polim IX No.126, Kelurahan

Melawai Kecamatan Kebayoran Baru Jakarta Selatan berasal dari teman. Konsumen berkunjung ke Restoran GadoGado Boplo 1 - 2 kali dalam sebulan.

Sebanyak 79 orang konsumen mengetahui daftar menu yang ditawarkan Restoran Gado-Gado Boplo. Rata-rata jumlah pengeluaran konsumen dalam sekali pembelian sebesar Rp. 50.000 - 100.000.

\section{Menu yang sering dipesan maupun dipilih saat pembelian}

Ditinjau dari aspek menu yang sering di pesan maupun dipilih saat pembelian karakteristik konsumen Restoran Gado-Gado Boplo dapat dilihat pada

Tabel 11 berikut.

Tabel 11. Identitas responden berdasarkan menu yang sering dipesan maupun dipilih saat pembelian di Restoran Gado-Gado Boplo Panglima Polim tahun 2015

\begin{tabular}{|l|l|l|l|}
\hline $\begin{array}{l}\text { N } \\
\text { o }\end{array}$ & $\begin{array}{l}\text { Menu yang } \\
\text { sering } \\
\text { dipilih/dipes } \\
\text { an }\end{array}$ & $\begin{array}{l}\text { Jumlah } \\
\text { Respond } \\
\text { en }\end{array}$ & $\begin{array}{l}\text { Presenta } \\
\text { se (\%) }\end{array}$ \\
\hline 1 & Gado-Gado & 75 & $76.2 \%$ \\
\hline 2 & Nasi Rames & 4 & $3.1 \%$ \\
\hline 3 & Nasi Timbel & 2 & $1.5 \%$ \\
\hline 4 & Ketoprak & 2 & $1.5 \%$ \\
\hline 5 & Karedok & 2 & $1.5 \%$ \\
\hline 6 & Soto Betawi & 3 & $6.9 \%$ \\
\hline 7 & Nasi Gudeg & 4 & $2.3 \%$ \\
\hline 8 & Nasi Bakar & 2 & $2.3 \%$ \\
\hline 9 & Lainnya & 6 & $4.6 \%$ \\
\hline & Total & $\mathbf{1 0 0}$ & $\mathbf{1 0 0}$ \\
\hline
\end{tabular}

Sumber: Data sekunder (Restoran GadoGado Boplo)

Dari Tabel 11 dapat diketahui menu yang sering dipesan maupun dipilih saat pembelian. Pada tabel di atas, diketahui bahwa 75 responden memilih gadogado sebagai menu yang disukai dan menu pilihan dengan persentase $76.2 \%, 6$ responden memilih lainnya yaitu sayur asem dan sop buntut sebagai menu yang disukai dan menu pilihan dengan persentase $4.6 \%, 4$ responden memilih nasi rames sebagai menu yang disukai dan menu pilihan dengan persentase 3.1\%, 4 responden memilih nasi gudeg sebagai menu yang disukai dan menu pilihan dengan persentase $2.3 \%, 3$ orang memilih soto betawi sebagai menu yang disukai dan menu pilihan dengan presentase $6.9 \%, 2$ orang responden memilih nasi bakar sebagai menu yang disukai dan menu pilihan dengan presentase $2.3 \%, 2$ responden memilih karedok sebagai menu yang disukai dan menu pilihan dengan presentase $1.5 \%, 2$ orang memilih ketoprak sebagai menu yang disukai dan menu pilihan dengan presentase $1.5 \%$, dan 2 responden memilih nasi timbel sebagai 
menu yang disukai dan menu pilihan dengan presentase $1.5 \%$. Hal ini berarti menu yang sering dipesan maupun dipilih saat pembelian adalah Gado-Gado sebagai menu favorit, dikarenakan menu andalan dari Restoran Gado-Gado Boplo, selain itu harga yang ditawarkan cukup terjangkau bagi kalangan manapun.

\section{Kepuasan Konsumen Terhadap Restoran Gado-Gado Boplo}

Ditinjau dari aspek kepuasan konsumen terhadap Restoran GadoGado

Boplo karakteristik konsumen Restoran Gado-Gado Boplo dapat dilihat pada Tabel 12 berikut.

Tabel 12. Identitas Responden Berdasarkan Kepuasan Konsumen terhadap

Restoran Gado-Gado Boplo di Restoran Gado- Gado Boplo Panglima Polim tahun 2015

\begin{tabular}{|l|l|l|l|l|l|}
\hline $\begin{array}{l}\text { N } \\
\text { o }\end{array}$ & $\begin{array}{l}\text { Kepuasan } \\
\text { konsumen } \\
\text { berdasarka } \\
\text { n: }\end{array}$ & $\begin{array}{l}\text { Sang } \\
\text { at } \\
\text { puas }\end{array}$ & $\begin{array}{l}\text { Pua } \\
\text { s }\end{array}$ & $\begin{array}{l}\text { Bias } \\
\text { a } \\
\text { saja }\end{array}$ & $\begin{array}{l}\text { Tida } \\
\text { k } \\
\text { puas }\end{array}$ \\
\hline 1 & Cita Rasa & 76 & 11 & 11 & 1 \\
\hline 2 & $\begin{array}{l}\text { Pelayanan } \\
\text { (service) }\end{array}$ & 69 & 14 & 17 & 0 \\
\hline 3 & Harga & 63 & 9 & 27 & 1 \\
\hline 4 & Keamanan & 62 & 7 & 31 & 0 \\
\hline 5 & $\begin{array}{l}\text { Kenyamana } \\
\text { n }\end{array}$ & 72 & 9 & 19 & 0 \\
\hline
\end{tabular}

Sumber: Data Primer (diolah)

Dari Tabel 12 dapat diketahui kepuasan konsumen terhadap Restoran Gado-Gado Boplo. Pada tabel di atas, diketahui bahwa 76 responden sangat puas terhadap Restoran Gado-Gado Boplo karena cita rasa, 72 responden sangat puas terhadap Restoran Gado-Gado Boplo karena kenyamanan, 69 responden sangat puas terhadap Restoran Gado-Gado Boplo karena pelayanan (service), 63 responden sangat puas terhadap Restoran Gado-Gado Boplo karena harganya relatif murah, dan 62 reponden sangat puas terhadap Restoran Gado-Gado Boplo karena keamanan terutama pada parkiran. Hal ini berarti konsumen Restoran Gado-Gado Boplo memiliki kepuasan berdasarkan cita rasa pada setiap menu makanan yang disajikan, dikarenakan bahan baku yang digunakan masih menggunakan warisan secara turuntemurun, sehingga cita rasa yang dihasilkan tidak berubah.

\section{Pengujian Uji Validitas dan Reliabilitas}

Uji validitas digunakan untuk mengukur valid atau tidaknya suatu kuesioner. Pengujian validitas dalam penelitian ini menggunakan rumus product moment dari Pearson yang dilakukan dengan menghitung korelasi antar masingmasing skor item pertanyaan dari tiap variabel dengan total skor variabel tersebut. Untuk menentukan butir yang dinyatakan valid atau tidak yaitu dengan

membandingkan $r$ hitung dengan $r$ tabel $=0,195$ pada taraf signifikan $\alpha=0,05$. Jika hasil perhitungan diperoleh $\mathrm{r}$ hitung $>$ dari $\mathrm{r}$ tabel maka butir instrumen dianggap valid, sebaliknya jika $\mathrm{r}$ hitung $<\mathrm{r}$ tabel maka dianggap tidak valid.

Berdasarkan hasil uji validitas menunjukan sebagian besar variabel (observed) adalah valid, dengan tingkat signifikansi 5\% $\alpha=0,05, \mathrm{n}=100$ diperoleh $r$ tabel $(0,195)$. Pembuktian ini menunjukkan bahwa sebagian besar variabel (observed) layak digunakan sebagai indikator dari konstruk (laten 
variabel). Hasil pengujian validitas dapat dilihat pada Lampiran 3.

Uji reliabilitas digunakan untuk mengukur konsistensi konstruk atau variable penelitian. Suatu variabel dikatakan reliable (handal) jika jawaban responden terhadap pertanyaan konsisten atau stabil dari waktu ke waktu. Tingkat reliabilitas suatu konstruk atau variabel penelitian dapat dilihat dari hasil statistik Cronbach Alpha $(\alpha)$ Suatu variabel dikatakan reliable jika memberikan nilai cronbach alpha $>0,60$. Koefisien alpha (Cronbach alpha) memiliki nilai diatas $\mathrm{r}$ tabel $(0,195)$ atau juga diatas 0,60 sehingga dapat dijelaskan bahwa variabel - variabel penelitian (konstruk) yang berupa variabel budaya, sosial, pribadi, dan psikologi dan keputusan pembelian adalah reliabel atau memiliki reliabilitas yang tinggi, sehingga mempunyai ketepatan yang tinggi untuk dijadikan variabel (konstruk) pada sumber penelitian. Hasil perhitungan reliabilitas oleh SPSS 18 dapat dilihat pada Lampiran 3.

\section{Uji Asumsi Klasik}

Validasi model melalui uji asumsi klasik dilakukan untuk mengetahui apakah hasil estimasi regresi linear berganda yang dilakukan telah terbebas dari gejala heteroskedastisitas, multikoliniearitas, dan normalitas.

\section{Uji Normalitas}

Uji normalitas digunakan untuk mengetahui apakah populasi data berdistribusi normal atau tidak, serta bertujuan untuk menguji apakah dalam model regresi, variabel penggangu atau residual memilki distribusi normal. Hasil uji normalitas penelitian ini dapat dilihat dari grafik p-plot Gambar 8 dibawah ini.

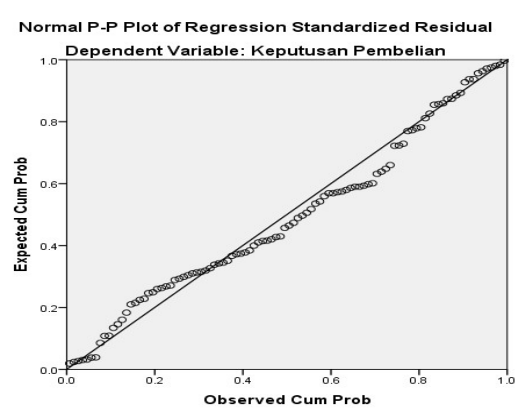

Gambar 8. Grafik P-Plot pengaruh faktor budaya, sosial, pribadi, dan psikologi konsumen terhadap keputusan pembelian

(Sumber data: primer, diolah)

Hasil uji normalitas dengan normal probability plot menunjukkan bahwa titiktitik menyebar tidak terlalu jauh pada sumbu diagonal p-plot, sehingga dapat dikatakan data terdistribusi normal dan memenuhi asumsi normalitas secara normal.

Deteksi uji normalitas dilakukan dengan melihat penyebaran data pada sumbu diagonal p-plot, jika data menyebar disekitar dan mengikuti garis diagonal model regresi memenuhi asumsi normalitas (Ghozali 2011:163). Hasil penelitian ini menunjukkan bahwa data memenuhi asumsi normalitas.

\section{Uji Multikolinieritas}

Uji multikolinieritas digunakan untuk menguji apakah pada model regresi ditemukan adanya korelasi diantara variabel independen. Model regresi yang baik seharusnya tidak terjadi korelasi diantara variabel independen karena akan mengurangi keyakinan dalam pengujian signifikansi. Hasil uji multikolinieritas penelitian ini dapat dilihat pada tabel 13 . 
Tabel 13. Multikolinieritas

\begin{tabular}{|l|l|l|}
\hline \multirow{2}{*}{ Model } & \multicolumn{2}{|l|}{ Collinearity Statistics } \\
\cline { 2 - 3 } & Tolerence & FIV \\
\hline Faktor Budaya (X1) & 0,900 & $\mathbf{1 , 1 1 1}$ \\
\hline Faktor Sosial (X2) & 0,861 & $\mathbf{1 , 1 6 2}$ \\
\hline Faktor Pribadi (X3) & 0,653 & $\mathbf{1 , 5 3 1}$ \\
\hline Faktor Psikologi (X4) & 0,754 & $\mathbf{1 , 3 2 6}$ \\
\hline
\end{tabular}

Sumber : data primer (diolah)

Dari tabel multikolinieritas diatas menunjukan bahwa VIF untuk faktor budaya, faktor sosial, faktor pribadi, dan psikologi memilki nilai VIF disekitar angka 1 , dan $<10$. Tolerance dari tabel 13 memiliki nilai mendekati 1 dan memilki nilai $>0,1$. Kesimpulan dari tabel 13 adalah tidak terjadi gejala multikolinieritas antara variabel independen dalam model regresi. Hal ini sesuai dengan pendapat Santoso (2014:183) bahwa deteksi tidak adanya multikolinieritas ditandai jika: 1) mempunyai nilai VIF disekitar angka 1,2) mempunyai angka tolerance mendekati 1 . Dasar pengambilan keputusan, jika nilai VIF (Variant Inflation Factor) lebih besar dari 10, maka terjadi gejala multikolinearitas, sebaliknya apabila nilai VIF (Variant Inflation Factor) lebih kecil dari 10, maka tidak terjadi gejala multikolinearitas diantara variabel bebas.

Berdasarkan hasil uji multikolinearitas yang terdapat pada tabel 13, diketahui bahwa, Faktor Budaya $\left(\mathrm{X}_{1}\right)$ memiliki VIF sebesar 1,111 dengan nilai tolerance 0,900, Faktor Sosial $\left(\mathrm{X}_{2}\right)$ memiliki VIF sebesar 1,162 dengan nilai tolerance 0,861, Faktor Pribadi $\left(\mathrm{X}_{3}\right)$ memiliki VIF sebesar 1,531 dengan nilai tolerance 0,653, dan Faktor Psikologi (X4) memilki VIF sebesar 1,326 dengan nilai tolerance 0,754 . Hasil output dari program SPSS 18 yang terdapat pada tabel

diatas maka dapat disimpulkan bahwa tidak mempunyai persoalan multikolinearitas antara variabel bebas dalam model regresi yang digunakan, karena keempat variabel memiliki nilai VIF $<10$ dan tolerance mendekati 1.

\section{Heteroskedastisitas}

Uji heteroskedastisitas digunakan untuk melihat apakah dalam model regresi terjadi ketidaksamaan variabel dari residual satu pengamatan ke pengamatan yang lain. Jika varian dari residual satu pengamatan ke pengamatan lain tetap, maka disebut homoskedastisitas, dan jika berbeda disebut heteroskedastisitas. Model regresi yang baik adalah tidak terjadi

heteroskedastisitas. Hasil uji heterokedastisitas penelitian ini dapat dilihat pada Gambar 9.

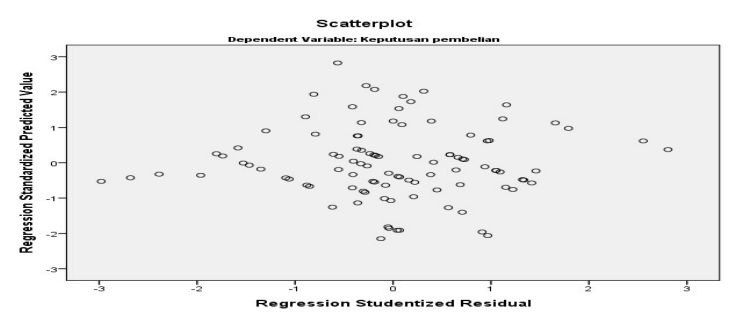

Gambar 9. Grafik Scatter plot pengaruh faktor budaya, sosial, pribadi, dan psikologi konsumen terhadap keputusan pembelian

(Sumber data: primer, diolah)

Dari Gambar 9 menunjukan bahwa titik-titik menyebar secara acak, serta tersebar diatas maupun dibawah angka 0 pada sumbu y, sehingga dapat disimpulkan bahwa tidak terdapat gejala 
heteroskedastisitas pada model regresi yang digunakan. Dasar pengambilan keputusan uji heteroskedastisitas yaitu jika tidak ada pola yang jelas dari scatter plot, serta titiktitik menyebar diatas dan dibawah angka 0 pada sumbu $y$, tidak terjadi heteroskedastisitas. Regresi dapat dilihat apakah terjadi heteroskedastisitas dari scatter plot yang dihasilkan (Ghozali

2011:139).

Hasil Analisis Regresi Linier Berganda

Hasil regresi berganda terdapat beberapa indikator yang mempengaruhi pembelian konsumen di Restoran GadoGado Boplo. Faktor-faktor yang diasumsikan berpengaruh terhadap keputusan konsumen dalam membeli makanan di Restoran Gado-Gado Boplo adalah faktor budaya, faktor sosial, faktor pribadi, dan faktor psikologi.

Kuisioner yang sudah valid dan reliabel dengan 31 butir pertanyaan dilakukan pengolahan dengan menggunakan analisis regresi berganda. Data dari masing-masing variabel yang telah valid dan reliabel diuji dengan uji asumsi klasik bertujuan untuk prasyarat analisis regresi. Data yang telah memenuhi syarat normalitas, terbebas dari gejala multikolinieritas, dan memenuhi syarat heteroskedastisitas dapat dipakai untuk analisis lebih lanjut. Analisis regresi berganda digunakan untuk uji hipotesis, diantaranya uji t, uji f, dan uji $\mathrm{R}^{2}$.

Alat analisis regresi berganda dengan bantuan software SPSS 18 digunakan untuk mengetahui pengaruh faktor budaya, faktor sosial, faktor pribadi dan faktor psikologi terhadap keputusan pembelian konsumen di Restoran GadoGado Boplo. Besarnya pengaruh yang ditimbulkan oleh faktor budaya, faktor sosial, faktor pribadi dan faktor psikologi diduga mempengaruhi pembelian konsumen dijabarkan pada Tabel 14.

Tabel 14 Hasil Regresi Pengaruh Faktor Budaya, Sosial, Pribadi, dan Psikologi Konsumen Terhadap Keputusan Pembelian di Restoran Gado-Gado Boplo Panglima Polim Jakarta Selatan

\begin{tabular}{|c|c|c|c|c|c|}
\hline \multirow[t]{2}{*}{ Model } & \multicolumn{2}{|c|}{$\begin{array}{l}\text { Unstandardize } \\
\text { d Coefficients }\end{array}$} & \multirow{2}{*}{$\begin{array}{l}\text { Standardize } \\
d \\
\text { Coefficients } \\
\text { Beta }\end{array}$} & \multirow[t]{2}{*}{$\mathrm{T}$} & \multirow[t]{2}{*}{ Sig. } \\
\hline & B & $\begin{array}{l}\text { Std. } \\
\text { Error }\end{array}$ & & & \\
\hline $\begin{array}{l}\text { (Constan } \\
\text { t) }\end{array}$ & 5.165 & $\begin{array}{l}2.01 \\
1\end{array}$ & & $\begin{array}{l}2.56 \\
9\end{array}$ & $\begin{array}{l}.01 \\
2\end{array}$ \\
\hline $\begin{array}{l}\text { Budaya } \\
\text { (X1) }\end{array}$ & $\begin{array}{l}.11 \\
9 \\
\end{array}$ & .053 & .176 & $\begin{array}{l}2.25 \\
8\end{array}$ & $\begin{array}{l}.02 \\
6\end{array}$ \\
\hline $\begin{array}{l}\text { Sosial } \\
(\mathrm{X} 2)\end{array}$ & $\begin{array}{l}.35 \\
8 \\
\end{array}$ & .076 & .378 & $\begin{array}{l}4.73 \\
6 \\
\end{array}$ & $\begin{array}{l}.00 \\
0\end{array}$ \\
\hline $\begin{array}{l}\text { Pribadi } \\
\text { (X3) }\end{array}$ & $\begin{array}{l}.15 \\
6\end{array}$ & .068 & .211 & $\begin{array}{l}2.30 \\
1\end{array}$ & $\begin{array}{l}.02 \\
4\end{array}$ \\
\hline $\begin{array}{l}\text { Psikologi } \\
(\mathrm{X} 4)\end{array}$ & $\begin{array}{l}.16 \\
4 \\
\end{array}$ & .060 & .234 & $\begin{array}{l}2.74 \\
7 \\
\end{array}$ & $\begin{array}{l}.00 \\
7 \\
\end{array}$ \\
\hline \multicolumn{2}{|c|}{$\mathrm{RSquare}_{=} .479$} & \multicolumn{4}{|c|}{$t_{\text {tabel }}=1,96$} \\
\hline \multirow{2}{*}{\multicolumn{3}{|c|}{$\begin{array}{l}F_{\text {hitung }}=21.830 \quad \alpha \\
95 \%) \\
F_{\text {tabel }}=2,467494(2,47)\end{array}$}} & (tingkat kepe & cayaan & \\
\hline & & & & & \\
\hline
\end{tabular}

Sumber : Data Primer, 2015 (Diolah).

Berdasarkan hasil analisis regresi pada Tabel 14, dapat dibuat model keputusan pembelian Gado-Gado Boplo untuk faktor-faktor yang mempengaruhi keputusan pembelian konsumen di Restoran Gado-Gado Boplo. Adapun model keputusan pembelian tersebut sebagai berikut:

$Y=5,165+0,119\left(X_{1}\right)+0,358\left(X_{2}\right)+0,156$ $\left(X_{3}\right)+0,164\left(X_{4}\right)$ 
Keterangan dari hasil regresi yang didapat yaitu:

1) $5,165:$ konstanta

2) $0,119:$ koefisien regresi variabel budaya

3) $0,358:$ koefisien regresi variabel sosial

4) $0,156:$ koefisien regresi variabel pribadi

5) $0,164:$ koefisien regresi variabel psikologi

Berdasarkan hasil model keputusan pembelian, diperoleh nilai konstanta sebesar 5,165, artinya bahwa keputusan pembelian konsumen di Restoran GadoGado Boplo bernilai positif, jika faktor lain tidak ada. Model di atas juga menunjukkan bahwa hasil koefisien regresi sebagai berikut :

Berdasarkan hasil analisis keputusan pembelian, didapat koefisien regresi faktor budaya $\left(\mathrm{X}_{1}\right)$ bernilai positif menunjukkan hubungan yang searah antara faktor budaya $\left(\mathrm{X}_{1}\right)$ terhadap keputusan pembelian konsumen $(\mathrm{Y})$.

Berdasarkan hasil analisis keputusan pembelian, didapat koefisien regresi faktor sosial $\left(\mathrm{X}_{2}\right)$ bernilai positif menunjukkan hubungan yang searah antara faktor sosial $\left(\mathrm{X}_{2}\right)$ terhadap keputusan pembelian konsumen $(\mathrm{Y})$.

Berdasarkan hasil analisis keputusan pembelian, didapat koefisien regresi faktor pribadi $\left(\mathrm{X}_{3}\right)$ bernilai positif menunjukkan hubungan yang searah antara faktor pribadi $\left(\mathrm{X}_{3}\right)$ terhadap keputusan pembelian konsumen $(\mathrm{Y})$.
Berdasarkan hasil analisis keputusan pembelian, didapat koefisien regresi faktor psikologi $\left(\mathrm{X}_{4}\right)$ bernilai positif menunjukkan hubungan yang searah antara faktor psikologi $\left(\mathrm{X}_{4}\right)$ terhadap keputusan pembelian konsumen (Y).

\section{Uji- Statistik t (Pengujian Parameter Regresi secara tunggal / parsial)}

Berdasarkan hasil uji $\mathrm{t}$ dengan tingkat kepercayaan 95 persen $(\alpha=0,05)$, variabel independen (faktor budaya, sosial, pribadi, dan psikologi) berpengaruh nyata terhadap keputusan pembelian konsumen. Uji ini dilakukan dengan

memperbandingkan thitung dengan tabel, (terima $\mathrm{H}_{0}$ jika thitung $<\mathrm{t}_{\text {tabel }}$ atau tolak $\mathrm{H}_{0}$ jika thitung $>t_{\text {tabel }}$ ) atau dari perbandingan probabilitasnya $(\mathrm{Sig}<\alpha)$, yaitu masingmasing berdasarkan hipotesis keputusan pembelian, yaitu:

$\mathrm{H}_{0}$ : tidak terdapat pengaruh faktor Budaya, Sosial, Pribadi, dan Psikologi konsumen terhadap keputusan pembelian

$\mathrm{H}_{1}$ : ada pengaruh faktor Budaya, Sosial, Pribadi, dan Psikologi konsumen terhadap keputusan pembelian

Dengan membandingkan nilai $t$ hitung dengan $\mathrm{t}$ tabel secara parsial maka dapat dijelaskan sebagai berikut ini.

1. Pengujian faktor budaya $\left(\mathrm{X}_{1}\right)$ terhadap keputusan pembelian konsumen $(\mathrm{Y})$

Berdasarkan hasil perhitungan olah SPSS 18 pada tingkat kepercayaan 95 persen dengan nilai signifikansi 0,026 dalam tabel 14 , nilai thitung untuk faktor budaya adalah sebesar $2,258>\mathrm{t}_{\text {tabel }}=$ 1,96 atau tingkat signifikansinya lebih 
kecil $\alpha$, yaitu $0,026<(0,05)$ dengan demikian dapat disimpulkan, bahwa tolak

$\mathrm{H}_{0}$ (thitung $>\mathrm{t}_{\text {tabel }}$; Sig $<\alpha$ ), yang berarti bahwa faktor budaya berpengaruh

nyata atau signifikan secara statistik terhadap keputusan pembelian konsumen. 2. Pengujian faktor sosial $\left(\mathrm{X}_{2}\right)$ terhadap keputusan pembelian konsumen (Y) Berdasarkan hasil perhitungan olah SPSS 18 pada tingkat kepercayaan 95 persen dengan nilai signifikansi 0,000 dalam Tabel 14, nilai thitung untuk faktor sosial adalah sebesar 4,736 $>$ tabel $=1,96$ atau tingkat signifikansinya lebih kecil $\alpha$, yaitu $0,000<$ $(0,05)$, dengan demikian dapat disimpulkan bahwa tolak

$\mathrm{H}_{0}$ ( $\mathrm{t}_{\text {hitung }}>\mathrm{t}_{\text {tabel }} ; \mathrm{Sig}<\alpha$ ), yang berarti bahwa faktor sosial berpengaruh nyata

atau signifikan secara statistik terhadap keputusan pembelian konsumen.

3. Pengujian faktor pribadi $\left(\mathrm{X}_{3}\right)$ terhadap keputusan pembelian konsumen (Y) Berdasarkan hasil perhitungan olah SPSS 18 pada tingkat kepercayaan 95 persen dengan nilai signifikansi 0,024 dalam Tabel 14, nilai thitung untuk faktor pribadi adalah sebesar $2.301>t_{\text {tabel }}=1,96$ atau tingkat signifikansinya lebih kecil $\alpha$, yaitu $0,024<(0,05)$, dengan demikian, dapat disimpulkan bahwa tolak

$\mathrm{H}_{0}$ (thitung $>\mathrm{t}_{\text {tabel }} ; \mathrm{Sig}<\alpha$ ), yang berarti bahwa faktor pribadi berpengaruh

nyata atau signifikan secara statistik terhadap keputusan pembelian konsumen.
4. Pengujian faktor psikologi $\left(\mathrm{X}_{4}\right)$ terhadap keputusan pembelian konsumen (Y)

Berdasarkan hasil perhitungan olah SPSS 18 pada tingkat kepercayaan 95 persen dengan nilai signifikansi 0,007 dalam Tabel 14, nilai thitung untuk faktor psikologi adalah sebesar 2,747 $>\mathrm{t}_{\text {tabel }}=$ 1,96 atau tingkat signifikansinya lebih kecil $\alpha$, yaitu $0,007<(0,05)$, dengan demikian, dapat disimpulkan bahwa tolak

$\mathrm{H}_{0}$ (thitung $>\mathrm{t}_{\text {tabel }} ; \mathrm{Sig}<\alpha$ ), yang berarti bahwa faktor psikologi berpengaruh

nyata atau signifikan secara statistik terhadap keputusan pembelian konsumen.

\section{Uji- Statistik F (Pengujian simultan seluruh parameter dugaan)}

Uji Statistik F, dalam penelitian ini digunakan untuk menunjukkan apakah semua variabel bebas (faktor budaya, sosial, pribadi, dan psikologi) yang dimasukkan dalam model mempunyai pengaruh secara bersama-sama terhadap variabel terikat (keputusan pembelian konsumen). Apabila nilai signifikansi lebih kecil dari 0,05 (sig< $0,05)$, maka model regresi signifikan secara statistik. Uji ini dapat dilakukan dengan memperbandingkan nilai $F_{h i t u n g}$ dengan $\mathrm{F}_{\text {tabel }}$ atau dari perbandingan probabilitasnya (Sig dengan $\alpha$ ).

Dengan Ketentuan:

$\mathrm{H}_{0}$ : ditolak, jika $\mathrm{F}_{\text {hitung }}>\mathrm{F}_{\text {tabel }}$, derajat bebas tertentu atau $\mathrm{Sig}<\alpha$

$\mathrm{H}_{1}$ : diterima, jika Fhitung $<\mathrm{F}_{\text {tabel }}$, derajat bebas tertentu atau Sig $>\alpha$ 
Tabel 15. Uji Signifikasi Simultan

\begin{tabular}{|l|l|l|l|l|}
\hline $\begin{array}{l}\text { No } \\
.\end{array}$ & Model & $\begin{array}{l}\text { Fhitun } \\
\mathrm{g}\end{array}$ & $\begin{array}{l}\text { Ftabe } \\
\mathrm{I}\end{array}$ & Sig \\
\hline 1. & $\begin{array}{l}\text { Regressio } \\
\mathrm{n} \\
\text { Residual } \\
\text { Total }\end{array}$ & 21,830 & 2,47 & $\begin{array}{l}0,000 \\
\mathbf{a}\end{array}$ \\
\hline
\end{tabular}

Ket.: Predicted Interval 95 persen

Berdasarkan hasil analisis dugaan parameter keputusan pembelian konsumen terkait bahwa uji signifikansi simultan (uji F) dengan tingkat kepercayaan 95 persen atau 0,05 , diperoleh nilai $F_{\text {hitung }}$ sebesar 21,830 dan $F_{\text {tabel }}$ sebesar 2,47 atau nilai signifikansi 0,000. Karena nilai $F_{\text {hitung }}>$ $F_{\text {tabel }}(21,830>2,47)$ atau nilai signifikansi sebesar 0,000 lebih kecil dari 0,05 (0,000 $<0,05$ ), maka dapat ditarik kesimpulan bahwa tolak $\mathrm{H}_{0}\left(\mathrm{~F}_{\text {hitung }}>\mathrm{F}_{\text {tabel }} ; \operatorname{Sig}<\alpha\right)$, artinya model regresi bisa dipakai untuk memprediksi keputusan pembelian konsumen dipengaruhi oleh faktor budaya, sosial, pribadi dan psikologi secara bersamasama. Hal ini sesuai dengan teori yang dikemukakan oleh Ghozali (2011:98), hasil uji $\mathrm{F}$ menunjukkan jika $\mathrm{F}$ hitung $>\mathrm{F}$ tabel dapat dikatakan bahwa variabel bebas memiliki pengaruh bersama-sama terhadap variabel terikat.

Hasil uji F pada Lampiran 7, tingkat signifikan sebesar $5 \%$ di peroleh df $1=4$, dan df $2=95$, maka didapat nilai f tabel yaitu 2,467494 atau di bulatkan menjadi 2,47. Nilai df1 merupakan hasil k-1, dimana $\mathrm{k}$ merupakan jumlah variabel bebas dan terikat yaitu 5, sedangkan nilai df2 merupakan hasil $\mathrm{n}-\mathrm{k}$, dimana $\mathrm{n}$ merupakan jumlah sampel yang digunakan dalam perhitungan analisis regresi yaitu 100 , sedangkan $\mathrm{k}$ merupakan jumlah variabel bebas dan terikat yaitu

\section{Uji -Statistik $\mathbf{R}^{2}$ (Koefisien Determinasi)}

Uji statistik $\mathrm{R}^{2} \quad$ (kofesien determinasi) digunakan untuk melihat seberapa besar faktor budaya, sosial, pribadi dan psikologi dalam menjelaskan keputusan pembelian konsumen. Cara menentukan koefesien determinasi dengan melihat kolom $\mathrm{R}^{2}$ dari hasil analisis SPSS (Mahendra, 2013). Rumus koefesien

determinasi adalah sebagai berikut :

$$
K D=R^{2} x \quad 100 \%
$$

Dengan dasar pengambilan keputusan

\begin{tabular}{|l|l|}
\hline$<0,10$ & Buruk ketepatanya \\
\hline $0,11-0,30$ & Rendah ketepatanya \\
\hline $0,31-0,50$ & Cukup ketepatanya \\
\hline$>0,50$ & Tinggi ketepatamya \\
\hline
\end{tabular}

Nilai koefesien determinasi pada penelitian ini dijabarkan pada tabel 16 Tabel 16. Koefisien Determinasi $\left(\mathrm{R}^{2}\right)$

\begin{tabular}{|l|l|l|l|l|l|}
\hline No & Model & $R$ & $\begin{array}{l}\text { R } \\
\text { Square }\end{array}$ & $\begin{array}{l}\text { Adjusted } \\
\text { R Square }\end{array}$ & $\begin{array}{l}\text { Std. Error } \\
\text { of the } \\
\text { Estimate }\end{array}$ \\
\hline 1 & 1 & $0,692^{\mathrm{a}}$ & 0,479 & 0,457 & 2,705 \\
\hline
\end{tabular}

Berdasarkan hasil pengujian regresi berganda, diperoleh nilai koefisien determinasi $\left(\mathrm{R}^{2}\right)$ sebesar 0,479 atau 47,9\%. Hal ini menunjukkan bahwa variabel tidak bebas (keputusan pembelian) mampu dijelaskan oleh variabel bebas (budaya, sosial, pribadi, dan psikologi) cukup baik terhadap keputusan pembelian memiliki kontribusi sebesar 47,9\%, Sedangkan sisanya sebesar $52,1 \%$ keputusan pembelian dipengaruhi oleh faktor lain diluar budaya, sosial, pribadi, dan psikologi. 


\section{Pembahasan}

Hasil analisis uji F, dapat diketahui bahwa nilai signifikasi sebesar 0.000 dan lebih kecil dari $\alpha=0,05$. Maka $\mathrm{H}_{0}$ ditolak, yang artinya variabel-variabel bebas yang diamati dengan tingkat kepercayaan 95\% yaitu Faktor Budaya, Faktor Sosial, Faktor Pribadi, dan Faktor Psikologi secara bersama-sama berpengaruh secara statistik terhadap Keputusan Pembelian di Restoran Gado-gado Boplo.

Hasil analisis uji-t, diketahui bahwa variabel Faktor Budaya, Faktor sosial Faktor Pribadi, dan Faktor Psikologi berpengaruh nyata atau signifikan terhadap keputusan pembelian di Restoran GadoGado Boplo pada tingkat kepercayaan 95\%. Dari hasil analisis penelitian masing-masing variabel dapat dijelaskan sebagai berikut.

\section{Faktor Budaya (X1) Berpengaruh Terhadap Keputusan Pembelian di Restoran Gado-Gado Boplo Panglima Polim}

Faktor budaya berpengaruh nyata atau signifikan secara statistik terhadap keputusan pembelian di Restoran GadoGado Boplo pada taraf kepercayaan 95\%. Hal ini di buktikan dengan hasil statistik uji$\mathrm{t}$ untuk faktor budaya diperoleh nilai $\mathrm{t}$ hitung sebesar 2,258 dan t tabel 1,96 dengan tingkat signifikansi 0,026, karena t hitung > t tabel $(2,258>1,96)$, signifikansi lebih kecil dari 0,05 $(0,026<0,05)$ dan koefesien regresi mempunyai nilai positif sebesar 0,119, maka faktor budaya berpengaruh positif terhadap keputusan pembelian di Restoran GadoGado Boplo Panglima Polim Jakarta Selatan.
Menurut Kotler (2005:153), faktor pertama yang mempengaruhi perilaku pembelian adalah faktor kebudayaan. Faktor kebudayaan merupakan penentu keinginan dan perilaku yang paling mendasar untuk mendapatkan nilai, persepsi, preferensi dan perilaku dari lembaga-lembaga penting lainnya. Faktor kebudayaan memberikan pengaruh paling luas pada tingkah laku konsumen. Faktor kebudayaan meliputi budaya, sub-budaya, dan kelas sosial. Budaya merupakan penyebab paling mendasar dari keinginan dan perilaku seseorang.

Berkaitan dengan karakteristik responden dari faktor budaya, bahwa penyedia produk Gado-Gado Boplo memberikan jam buka layanan pada hari libur. Hal ini sangat sesuai dengan fakta di lapangan bahwa responden sebanyak $47 \%$ bekerja sebagai Pegawai Negeri Sipil dan $14 \%$ bekerja sebagai pegawai swasta yang memiliki karakteristik terikat oleh waktu. Jenis pekerjaan yang dimiliki oleh responden mempengaruhi perilaku pembelian terhadap Gado-Gado Boplo, karena pada hari libur pegawai negeri sipil dan pegawai swasta lebih memiliki waktu yang luang untuk melakukan wisata kuliner.

Keterkaitan karakteristik responden dengan faktor budaya yang berpengaruh positif terhadap keputusan pembelian juga dapat dilihat dari sisi menu (produk) yang disediakan oleh pemilik Gado-Gado Boplo. Gado-Gado merupakan makanan khas Betawi, di mana secara administratif berasal dari DKI Jakarta. Sebagai makanan khas produk gado-gado memiliki daya tarik tersendiri, karena responden yang melakukan pembelian berdomisili di DKI Jakarta. 
Berdasarkan variabel faktor budaya indikator terdiri dari: kelas sosial, wilayah geografis, dan budaya konsumsi. Berikut merupakan pembahasan dari masingmasing indikator.

Kelas sosial: konsumen yang datang ke Restoran Gado-Gado Boplo sebagian besar adalah pekerja yang memiliki penghasilan cukup. Pengeluaran dalam sebulan konsumen Restoran Gado-Gado Boplo berkisar Rp.10.000.000, jumlah dari penghasilan sebesar ini menunjukkan bahwa responden merupakan pegawai yang memiliki posisi menengah (upper middle class), sehingga penghasilan yang dimiliki cukup untuk memenuhi kebutuhan hidup.

wilayah geografis: konsumen yang datang ke Restoran Gado-Gado Boplo sebagian besar berdomisili dari DKI Jakarta, sehingga mayoritas konsumen bertempat tinggal di wilayah Jakarta. Letak Restoran Gado-Gado Boplo strategis didekat area perkantoran, selain dekat dengan area perkantoran letak dari Restoran Gado-Gado Boplo berada tidak terlalu jauh dengan kampus (sekolahan), perumahan (pemukiman penduduk), tempat usaha (pusat bisnis). Akses Restoran berada pada jalan utama (protokol), sehingga memudahkan konsumen untuk dapat menjangkau menuju Restoran Gado-Gado Boplo. Jarak tempuh dari Restoran GadoGado Boplo ke tempat tinggal konsumen sekitar ${ }^{+}+5 \mathrm{~km}$, sedangkan jarak tempuh dari Restoran Gado-Gado Boplo ke tempat kerja konsumen ${ }_{-}^{+} 1-3 \mathrm{~km}$.

Budaya konsumsi: konsumen yang datang ke Restoran Gado-Gado Boplo mempunyai kebiasaan dalam melakukan kunjungan lebih dari satu kali kunjungan. Kebiasaan konsumen dalam melakukan kunjungan paling sering dilakukan pada hari weekend, dimana sebagian besar konsumen memanfaatkan waktu libur bersama keluarga, sehingga untuk memenuhi kebutuhan pangan melakukan pembelian di Restoran Gado-Gado Boplo.

Hasil penelitian mendukung penelitian terdahulu yang dilakukan oleh Puspitarini (2013) mengenai "pengaruh faktor kebudayaan, sosial, pribadi, dan psikologi terhadap proses keputusan pembelian produk pizza (studi pada pizza hut cabang jalan jenderal sudirman Yogyakarta)", dari hasil penelitian faktor budaya diperoleh nilai $\mathrm{t}$ hitung sebesar 2,589 dan $\mathrm{t}$ tabel 1,984 dengan tingkat signifikansi 0,011 , karena $\mathrm{t}$ hitung $>\mathrm{t}$ tabel $(2,589>1,984)$, signifikansi lebih kecil dari 0,05 $(0,011<0,05)$, dan koefesien regresi mempunyai nilai positif sebesar 0,218, sehingga dapat disimpulkan pada hipotesis pertama bahwa "faktor budaya berpengaruh positif secara parsial (individu) terhadap keputusan pembelian produk pizza pada Pizza Hut Jalan Jenderal Sudirman No.53 Yogyakarta".

\section{Faktor Sosial (X2) Berpengaruh Terhadap Keputusan Pembelian di

Restoran Gado-Gado Boplo
Panglima Polim

Faktor sosial berpengaruh nyata atau signifikan secara statistik terhadap keputusan pembelian di Restoran GadoGado Boplo pada taraf kepercayaan 95\%. Hal ini di buktikan dengan hasil statistik uji$\mathrm{t}$ untuk faktor sosial diperoleh nilai $\mathrm{t}$ hitung sebesar 4,736 dan $t$ tabel 1,96 dengan tingkat signifikansi 0,000, karena t hitung > 
t tabel $(4,736>1,96)$, signifikansi lebih kecil dari 0,05 $(0,000<0,05)$ dan koefesien regresi mempunyai nilai positif sebesar 0,358, maka faktor sosial berpengaruh positif terhadap keputusan pembelian di Restoran Gado-Gado Boplo Panglima Polim Jakarta Selatan.

Menurut Kotler (2005:153), faktor kedua yang memengaruhi perilaku pembelian adalah faktor sosial. Faktor sosial merupakan interaksi formal maupun informal dalam masyarakat yang relatif permanen yang anggotanya menganut minat dan perilaku serupa dalam usahanya mencapai tujuan bersama. Faktor sosial terdiri dari: kelompok acuan, keluarga, peran dan status.

Berkaitan dengan karakteristik responden dari faktor sosial, bahwa sebagian besar konsumen yang datang ke Restoran Gado-Gado Boplo dipengaruhi oleh lingkungan keluarga maupun lingkungan kerja. Bentuk pengaruh pada variabel ini ditunjukan oleh banyaknya konsumen yang memutuskan pembelian

Gado-Gado Boplo karena mengikuti rekan kerja maupun anggota keluarga. Responden sekaligus sebagai konsumen Restoran Gado-Gado Boplo memutuskan melakukan pembelian karena adanya testimoni positif yang disampaikan kepada keluarga maupun rekan kerja. Pada sebuah tatanan keluarga apabila salah satu atau lebih anggota keluarga memiliki suatu kebiasaan, maka anggota keluarga yang lain cenderung akan terbawa ataupun mengikuti kebiasaan tersebut.

Titik awal bergabungnya responden menjadi konsumen pada Gado-gado

Boplo dimulai dari keberhasilan pemilik restoran dalam melakukan promosi.
Tersedianya informasi mengenai produk Gado-Gado Boplo membuat konsumen mengetahui, terbujuk untuk mencoba, dan melakukan pembelian kembali karena merasa sesuai dengan karakteristik dirinya. Promosi merupakan salah satu alternatif yang sangat memikat konsumen untuk dapat melakukan pembelian produk. Promosi yang paling berhasil dalam konteks ini adalah mouth to mouth yang dilakukan oleh konsumen terhadap anggota keluarga maupun rekan kerja. Mouth to mouth memberikan pengaruh sangat besar karena berdasarkan sumber informasi secara langsung dari anggota keluarga, sehingga bertambahnya respon dari masing-masing anggota keluarga dalam melakukan pembelian.

Semakin besar pengaruh keluarga dalam melakukan pembelian mengindikasikan semakin tinggi proses keputusan pembelian produk, dan sebaliknya. Dalam hal ini dengan memperhatikan produk yang akan dikonsumsi dapat di terima dengan baik. Faktor sosial lainya yang mempengaruhi keputusan pembelian adalah kemudahan akses untuk menuju Restoran Gado-Gado Boplo.

Berdasarkan variabel faktor sosial indikator terdiri dari: keberadaan teman untuk memilih produk, keberadaan anggota keluarga untuk memilih produk, dan mengikuti lingkungan. Berikut merupakan pembahasan dari masing-masing

indikator.

Keberadaan teman untuk memilih produk: konsumen mengetahui

informasi Restoran Gado-Gado Boplo berasal dari teman, informasi diperoleh dari hasil komunikasi melalui (mouth to mouth) 
antara orang satu dengan yang lain, sehingga adanya timbal balik (feed back) yang menyebabkan konsumen melakukan pembelian. Dalam melakukan kunjungan kebanyakan konsumen datang bersama teman kerja pada jam makan siang yaitu pada jam 13.00-14.00, umumnya konsumen yang datang memanfaatkan waktu istirahat untuk bersantap

siang.

Keberadaan anggota keluarga dalam memilih produk: konsumen yang datang ke Restoran Gado-Gado Boplo memutuskan untuk melakukan pembelian karena adanya testimoni positif yang disampaikan kepada keluarga. Pada tatanan keluarga memiliki kebiasaan yang berbeda terutama dalam konsumsi pangan. Konsumsi pangan dalam keluarga di pengaruhi oleh faktor usia, diantaranya usia dewasa dan usia remaja. Usia remaja lebih menginginkan makanan yang serba praktis (cepat saji), sedangkan usia dewasa lebih cenderung untuk mengkonsumsi makanan yang sehat dan organik. Konsumen berkunjung ke Restoran Gado-Gado Boplo pada hari weekend (sabtu-minggu), karena memanfaatkan waktu libur untuk berkumpul bersama dengan keluarga.

Mengikuti lingkungan: konsumen yang melakukan pembelian di Restoran Gado-Gado Boplo dipengaruhi dari lingkungan tempat tinggal. Keinginan konsumen melakukan pembelian muncul karena tersedianya informasi mengenai produk dari Restoran Gado-Gado Boplo. Konsumen terbujuk untuk mencoba, mengetahui, dan melakukan pembelian karena sesuai dengan karakteristik dirinya. Informasi yang didapat oleh konsumen sebelum melakukan pembelian didapat dari teman, maupun keluarga. Kebiasaan mengikuti lingkungan dalam melakukan pembelian cenderung memiliki pengaruh lebih terhadap perilaku pembelian.

Hasil penelitian mendukung penelitian terdahulu yang dilakukan oleh puspitarini (2013) mengenai "pengaruh faktor kebudayaan, sosial, pribadi, dan psikologi terhadap proses keputusan pembelian produk pizza (studi pada pizza hut cabang jalan jenderal sudirman Yogyakarta), dari hasil penelitian faktor sosial diperoleh nilai $t$ hitung sebesar 4,076 dan $\mathrm{t}$ tabel 1,984 dengan tingkat signifikansi 0,000, karena $\mathrm{t}$ hitung $>\mathrm{t}$ tabel $(4,076>1,984)$, signifikansi lebih kecil dari 0,05 $(0,000<0,05)$, dan koefesien regresi mempunyai nilai positif sebesar 0,307, sehingga dapat disimpulkan pada hipotesis kedua bahwa "faktor sosial berpengaruh positif secara parsial (individu) terhadap keputusan pembelian produk pizza pada Pizza Hut Jalan Jenderal Sudirman No.53 Yogyakarta".

\section{Faktor Pribadi (X3) Berpengaruh Terhadap Keputusan Pembelian di \\ Restoran Gado-Gado Boplo Panglima Polim}

Faktor pribadi berpengaruh nyata atau signifikan secara statistik terhadap keputusan pembelian di Restoran GadoGado Boplo pada taraf kepercayaan 95\%.

Hal ini di buktikan dengan hasil statistik uji$\mathrm{t}$ untuk faktor pribadi diperoleh nilai $\mathrm{t}$ hitung sebesar 2,301 dan $t$ tabel 1,96 dengan tingkat signifikansi 0,024, karena t hitung > $\mathrm{t}$ tabel $(2,301>1,96)$, signifikansi lebih kecil dari 0,05 $(0,024<0,05)$ dan koefesien regresi mempunyai nilai positif sebesar 
0,156, maka faktor pribadi berpengaruh positif terhadap keputusan pembelian di Restoran Gado-Gado Boplo Panglima Polim Jakarta Selatan.

Menurut Kotler (2005:153), faktor ketiga yang mempengaruhi perilaku pembelian adalah faktor pribadi. Faktor pribadi didefinisikan sebagai karakteristik psikologis seseorang yang berbeda dengan orang lain menyebabkan tanggapan yang relatif konsisten dan bertahan lama terhadap lingkungan (Kotler dan Amstrong, 1997:151-153) Faktor pribadi terdiri dari: usia dan tahap siklus, pekerjaan, situasi ekonomi, gaya hidup, kepribadian dan konsep diri.

Berkaitan dengan karakteristik responden dari faktor pribadi bahwa sebagian besar konsumen yang datang ke Restoran Gado-Gado Boplo di pengaruhi oleh usia. Hal ini berdasarkan fakta yang terdapat di lapangan bahwa rata-rata konsumen yang datang sebanyak $86 \%$ pada usia 25-50 tahun sedangkan sebanyak 14\% pada usia 18-24 tahun, dikarenakan pada usia dewasa lebih cenderung memilki pola berpikir matang dibandingkan dengan usia remaja. Usia dewasa lebih cenderung memikirkan pola hidup sehat terutama dalam memilih konsumsi pangan salah satunya mengkonsumsi sayuran (vegetarian). Kondisi berbeda dialami pada usia remaja yang lebih cenderung mengikuti perkembangan gaya hidup modern terutama dalam memilih konsumsi pangan salah satunya menginginkan makanan cepat saji dan serba praktis (junk food). Responden yang melakukan pembelian di Restoran Gado-Gado Boplo lebih berada pada usia yang produktif yaitu 25-50 tahun. Pada usia produktif cenderung lebih mudah untuk berinteraksi dengan lingkungan kerja maupun keluarga.

Perilaku pengambilan keputusan pembelian akan sangat dipengaruhi oleh tingkat pendapatan konsumen. Pada usia produktif cenderung memiliki penghasilan lebih besar, dibanding dengan usia dibawahnya yang mungkin belum memiliki penghasilan sendiri. Keterkaitan karakteristik responden lain dari faktor pribadi bahwa kebanyakan konsumen yang datang ke Restoran Gado-Gado Boplo dipengaruhi oleh keadaan ekonomi atau jumlah pengeluaran. Hal ini berdasarkan fakta yang terdapat dilapangan bahwa ratarata pengeluaran konsumen dalam sebulan sebanyak $28 \%$ dengan jumlah pengeluaran sebulan sebesar Rp.6.000.000Rp.13.000.000, sedangkan sebanyak $27 \%$ dengan jumlah pengeluaran dalam sebulan sebesar Rp. 2.700.000- Rp. 6.000.000, hal ini dikarenakan konsumen yang datang merupakan kalangan kelas menengah atas karena sebagian besar pengeluaran konsumen dalam sebulan berkisar 10.000.000, dimana sebagian besar konsumen Restoran Gado-Gado Boplo adalah kalangan pekerja yang sudah cukup untuk memenuhi kebutuhan hidup.

\section{Gado-Gado Boplo merupakan} sebuah usaha dagang yang bergerak menyediakan kebutuhan pangan siap saji. Pangan merupakan salah satu kebutuhan pokok manusia yang paling mendasar, perubahan gaya hidup terhadap pola konsumsi pangan menyebabkan kebanyakan orang menyukai makanan yang serba praktis (cepat saji). Jenis pekerjaan responden memiliki karakter terikat oleh waktu yang berakibat tidak tersedianya waktu untuk memasak. Pada sisi lain jumlah pendapatan yang relatif tinggi memudahkan 
responden untuk melakukan pengambilan keputusan pembelian pada Restoran GadoGado Boplo.

Berdasarkan variabel faktor pribadi indikator terdiri dari: usia, pekerjaan, keadaan ekonomi (penghasilan), dan gaya hidup. Berikut merupakan pembahasan dari masing-masing indikator.

Usia: konsumen yang berkunjung ke Restoran Gado-Gado boplo didominasi oleh usia 25-50 tahun, dan 18-24 tahun. Usia 2550 tahun merupakan usia yang cenderung bersosialisasi dengan teman maupun keluarga dan mencoba hal yang baru. Usia ini tergolong dewasa dimana pola pikir yang dimiliki lebih matang terutama dalam memilih jenis makanan yang akan dibeli. Biasanya usia dewasa lebih cenderung memilih jenis makanan yang sehat untuk dikonsumsi contohnya seperti: sayuran, dan buah-buahan. Pada usia dewasa cenderung untuk memikirkan pola hidup sehat. Sedangkan usia 18-24 tahun merupakan usia yang masih senang untuk mencari hiburan, berkumpul dengan teman, dan mengikuti gaya hidup modern. Usia ini tergolong remaja dimana pola pikir yang dimiliki belum matang terutama dalam memilih jenis makanan yang akan dibeli. Biasanya usia remaja lebih cenderung memilih jenis makanan cepat saji (junk food) tanpa memikirkan pola hidup sehat, contohnya: KFC, dan MC DONALD'S. Pada usia remaja tidak mementingkan pola hidup sehat, sebagian besar menyukai makanan serba praktis untuk dikonsumsi.

Pekerjaan: konsumen yang berkunjung ke Restoran Gado-Gado Boplo sebagian besar berprofesi sebagai pegawai negeri karena letak kantornya berada tidak jauh dari restoran. Jarak tempuh dari
Restoran Gado-Gado Boplo ketempat kerja konsumen + 1-3 km. Rata-rata jumlah pengeluaran konsumen dalam sekali pembelian sebesar Rp.50.000-100.000.

Keadaan ekonomi atau penghasilan: konsumen yang berkunjung ke Restoran Gado-Gado Boplo adalah kalangan pekerja yang sudah cukup untuk memenuhi kebutuhan hidup. Jumlah pengeluaran konsumen dalam sebulan ${ }^{+}$_Rp.10.000.000, pengeluaran ini menunjukkan bahwa konsumen Restoran GadoGado Boplo tergolong kelas menengah atas yang memiliki penghasilan cukup untuk memenuhi kebutuhan hidup salah satunya pangan.

Gaya hidup: konsumen dari Restoran Gado-Gado Boplo didasarkan pada kepraktisan terhadap pola konsumsi. Pola konsumsi dari konsumen menginginkan makanan yang cepat saji (praktis), hal ini dikarenakan rutinitas pekerjaan yang padat sehingga tidak sempat untuk memasak makanan sendiri. Hal lain didominasi oleh pengeluaran perbulan dari konsumen Restoran Gado-Gado Boplo sebesar + _ Rp.10.000.000. Jumlah pengeluaran konsumen yang besar berpengaruh terhadap perubahan gaya hidup, semakin besar jumlah pengeluaran, maka semakin meningkat jumlah barang yang di beli.

Hasil penelitian mendukung penelitian terdahulu yang dilakukan oleh Puspitarini (2013) mengenai "pengaruh faktor kebudayaan, sosial, pribadi, dan psikologi terhadap proses keputusan pembelian produk pizza (studi pada pizza hut cabang jalan jenderal sudirman Yogyakarta), dari hasil penelitian faktor 
pribadi diperoleh nilai $\mathrm{t}$ hitung sebesar 5,352 dan $t$ tabel 1,984 dengan tingkat signifikansi 0,000 , karena $\mathrm{t}$ hitung $>\mathrm{t}$ tabel $(5,352>1,984)$, signifikansi lebih kecil dari 0,05

$(0,000<0,05)$, dan koefesien regresi mempunyai nilai positif sebesar 0,227 , sehingga dapat disimpulkan pada hipotesis ketiga bahwa "faktor pribadi berpengaruh positif secara parsial (individu) terhadap keputusan pembelian produk pizza pada Pizza Hut Jalan Jenderal Sudirman No.53 Yogyakarta".

\section{Faktor Psikologi (X4) Berpengaruh Terhadap Keputusan Pembelian di Restoran Gado-Gado Boplo Panglima Polim}

Faktor psikologi berpengaruh nyata atau signifikan secara statistik terhadap keputusan pembelian di Restoran GadoGado Boplo pada taraf kepercayaan 95\%. Hal ini di buktikan dengan hasil statistik uji$\mathrm{t}$ untuk faktor psikologi diperoleh nilai $\mathrm{t}$ hitung sebesar 2,747 dan $\mathrm{t}$ tabel 1,96 dengan tingkat signifikansi 0,007, karena t hitung > t tabel $(2,747>1,96)$, signifikansi lebih kecil dari 0,05 $(0,007<0,05)$ dan koefesien regresi mempunyai nilai positif sebesar

0,164, maka faktor psikologi berpengaruh positif terhadap keputusan pembelian di Restoran Gado-Gado Boplo Panglima Polim Jakarta Selatan.

Menurut Kotler (2005:153), faktor keempat yang mempengaruhi perilaku pembelian adalah faktor psikologi. Faktor psikologis sebagai bagian dari pengaruh lingkungan dimana ia tinggal dan hidup pada waktu sekarang tanpa mengabaikan pengaruh masa lampau atau antisipasinya terhadap waktu yang akan datang. Faktor psikologi meliputi: motivasi, persepsi, pengetahuan, keyakinan dan sikap. Semakin banyak pengetahuan yang dimiliki, tingginya keyakinan akan produk, serta ketegasan sikap dan kejelasan motivasi dalam memenuhi kebutuhannya terhadap suatu produk maka akan semakin besar proses keputusan pembelian produk tersebut.

Berkaitan dengan karakteristik responden dari faktor psikologi bahwa sebagian besar konsumen yang datang ke Restoran Gado-Gado Boplo dipengaruhi oleh menu yang sering dipesan maupun dipilih saat pembelian. Berdasarkan fakta yang terdapat dilapangan bahwa sebanyak $75 \%$ responden memilih gado-gado sebagai menu yang disukai dan menu pilihan dengan presentase $76,2 \%$, hal ini menunjukkan bahwa daya tarik utama Restoran Gado-Gado Boplo adalah menu Gado-Gado dan juga sebagian besar responden percaya, dan yakin terhadap produk dari Restoran Gado-Gado Boplo.

Berdasarkan variabel faktor psikologi indikator terdiri dari: motivasi, persepsi, pengetahuan, keyakinan dan sikap. Berikut merupakan pembahasan dari masing-masing indikator.

Motivasi: konsumen berkunjung ke Restoran Gado-Gado Boplo karena di pengaruhi oleh banyaknya pilihan menu makanan, sehingga menimbulkan daya tarik konsumen untuk melakukan pembelian. Kebutuhan akan rasa haus, dan lapar membuat konsumen berkunjung ke Restoran Gado-Gado Boplo untuk melakukan pembelian.

Persepsi : $\quad$ konsumen menginterpretasikan perolehan informasi dari berbagai sumber, diantaranya: media 
online, dan brosur mengenai Restoran GadoGado Boplo. Sumber informasi yang di interpretasikan cenderung akan mengingat informasi yang menyokong pandangan dan keyakinan, serta kepercayaan konsumen untuk melakukan pembelian.

Pengetahuan : konsumen yang berkunjung ke Restoran Gado-Gado Boplo mengetahui tentang apa yang diinginkan dan sejauh mana produk yang ditawarkan dari manajemen restoran. Pihak manajemen restoran berupaya memberikan informasi dari produk yang ditawarkan. Salah satunya dengan memberikan menu atau daftar makanan yang ditawarkan, sehingga sebelum melakukan pembelian konsumen memahami produk yang ditawarkan dari Restoran Gado-Gado Boplo.

Keyakinan : konsumen yang berkunjung ke Restoran Gado-Gado Boplo sebelum melakukan pembelian produk memiliki pemikiran yang matang serta tidak terpengaruh oleh produk lain. Konsumen yang sudah memiliki keyakinan dalam mengambil keputusan pembelian bersikap konsisten. Keyakinan konsumen untuk melakukan pembelian di Restoran GadoGado Boplo karena kualitas produk. Kualitas produk dari Restoran Gado-Gado Boplo menggunakan bahan organik salah satunya sayuran seperti: bayam organik, dan selada organik.

Sikap : konsumen yang berkunjung ke Restoran Gado-Gado Boplo mempunyai komitmen untuk melakukan pembelian. Komitmen didasari atas kepercayaan terhadap produk yang dibeli. Kepercayaan konsumen terhadap produk Restoran GadoGado Boplo, karena restoran ini dikelola secara turun - temurun sampai sekarang, sehingga resep dan cita rasa masakan tidak berubah, selain itu sayuran yang digunakan organik.

Hasil penelitian mendukung penelitian terdahulu yang dilakukan oleh Puspitarini (2013) mengenai "pengaruh faktor kebudayaan, sosial, pribadi, dan psikologi terhadap proses keputusan pembelian produk pizza (studi pada pizza hut cabang jalan jenderal sudirman Yogyakarta), dari hasil penelitian faktor psikologi diperoleh nilai $\mathrm{t}$ hitung sebesar 3,630 dan $\mathrm{t}$ tabel 1,984 dengan tingkat signifikansi

0,008 , karena $\mathrm{t}$ hitung $>\mathrm{t}$ tabel $(3,630>1,984)$, signifikansi lebih kecil dari 0,05

$(0,008<0,05)$, dan koefesien regresi mempunyai nilai positif sebesar 0,266 , sehingga dapat disimpulkan pada hipotesis keempat bahwa "faktor psikologi berpengaruh positif secara parsial (individu) terhadap keputusan pembelian produk pizza pada Pizza Hut Jalan Jenderal Sudirman No.53 Yogyakarta”.

\section{Faktor Budaya, Sosial, Pribadi, dan Psikologi Berpengaruh Terhadap Keputusan Pembelian di Restoran Gado-Gado Boplo}

\section{Panglima Polim}

Faktor budaya, sosial, pribadi, dan psikologi berpengaruh terhadap keputusan pembelian di Restoran Gado-Gado Boplo. Hal ini dibuktikan dengan hasil statistik uji f faktor budaya, sosial, pribadi, dan psikologi diperoleh nilai f hitung sebesar 21,830 dan f tabel sebesar 2,47 dengan signifikansi sebesar 0,000, karena f hitung > f tabel $(21,830>2,47)$ dengan nilai signifikansi sebesar 0,000 lebih kecil dari 
$0,05(0,000<0,05)$, maka model regresi bisa dipakai untuk memprediksi keputusan pembelian konsumen atau faktor budaya, sosial, pribadi dan psikologi secara simultan (bersama-sama) berpengaruh secara statistik terhadap keputusan pembelian konsumen.

Variabel bebas terhadap variabel terikat secara bersama-sama dapat dilihat dari hasil pengujian koefesien determinasi $\left(\mathrm{R}^{2}\right)$ dan hasil uji $\mathrm{f}$ atau uji simultan. Tabel 15 menunjukkan bahwa variabel terikat mampu dijelaskan oleh variabel bebas sudah baik, sedangkan sisanya 52,1\% keputusan pembelian dipengaruhi oleh faktor lain diluar budaya, sosial, pribadi, dan psikologi antara lain harga, pelayanan, dan kualitas produk yang tidak dimasukan dalam penelitian ini, Kotler (2008:102).

\section{Menurut Kotler (2005:202),} keputusan pembelian adalah tahap dalam proses pengambilan keputusan pembeli di mana konsumen benar-benar membeli.

Pengambilan keputusan merupakan suatu kegiatan individu yang secara langsung terlibat, dalam mendapatkan dan mempergunakan barang yang ditawarkan.

Berkaitan dengan karakteristik responden dari keputusan pembelian sebagian besar konsumen yang datang ke Restoran Gado-Gado Boplo dipengaruhi oleh alasan membeli produk makanan di Restoran Gado-Gado Boplo. Berdasarkan fakta yang terdapat dilapangan bahwa sebanyak $57 \%$ responden memilih kualitas produk sebagai salah satu alasan untuk dapat berkunjung ke Restoran Gado-Gado Boplo, dikarenakan kualitas produk merupakan penentu yang paling utama dalam pembelian, hal ini dikarenakan bahan yang digunakan untuk mengolah produk makanan menggunakan bahan yang organik terutama sayuran, selain itu resep yang digunakan masih secara turun temurun, sehingga tidak merubah kualitas rasa, keterkaitan karakteristik responden lain dari keputusan pembelian diantaranya melakukan pengenalan masalah, pencarian informasi, evaluasi alternatif, keputusan pembelian, perilaku pasca pembelian.

Tahap pengenalan masalah menjurus pada proses pembelian yang dimulai pada saat pembeli menyadari adanya suatu kebutuhan yang harus dipenuhi dalam hidup, salah satunya pangan. Pangan merupakan salah satu kebutuhan pokok mendasar manusia yang harus terpenuhi, sehingga tanpa adanya pangan manusia tidak dapat bertahan hidup untuk melakukan kegiatan maupun aktivitas seharihari. Tahap selanjutnya adalah pencarian informasi, proses pembelian dilakukan pada saat konsumen mengetahui produk yang akan dibeli. Sumber informasi produk yang akan dibeli dapat diperoleh dari teman (relasi), keluarga, lingkungan tempat tinggal, dan melalui browsing (kegiatan online). Masing-masing sumber informasi sangat mempengaruhi konsumen dalam melakukan pembelian. Hasil penelitian menunjukkan kebanyakan konsumen mengetahui informasi produk Restoran Gado-Gado Boplo dari keluarga dan teman (relasi). Kedua sumber informasi tersebut sangat akurat karena menggunakan cara (mouth to mouth) atau dari mulut ke mulut sebagai media informasi, sehingga informasi produk yang akan dibeli lebih efektif dan sesuai dengan keinginan konsumen (responden).

Tahap evaluasi menjurus kepada proses pembelian dimulai pada saat konsumen berusaha memuaskan kebutuhan, 
mencari manfaat dari solusi produk, melihat masing-masing produk. Proses evaluasi dapat dilihat dari: kualitas produk, promosi, harga, lokasi, dan kebutuhan sehari-hari atau gaya hidup. Kebutuhan konsumen dalam melakukan pembelian didasarkan dari kualitas, karena kualitas merupakan mutu dari produk yang akan dijual ke konsumen. Kualitas yang terdapat di Restoran Gado-Gado Boplo yaitu rasa, bahan yang akan diolah, dan jaminan kehalalan. Promosi yang ditawarkan oleh Restoran Gado- Gado Boplo yaitu dengan memberikan discount kepada konsumen yang berkunjung sebanyak 10 kali akan diberikan bonus voucher senilai Rp 50.000, kriteria yang dimiliki bagi konsumen yang memiliki kartu kredit bank bukoupin diberikan discount $20 \%$ dan bagi yang memiliki kartu kredit bank muamalat diberikan discount sebesar 30\%. Harga yang terdapat pada Restoran Gado-Gado Boplo range Rp 30.000 - 100.000, harga tersebut tidak terlalu mahal dan masuk kedalam golongan kelas menengah. Lokasi Restoran Gado-Gado Boplo memiliki letak yang sangat strategis berada di pusat ibu kota Jakarta, akses menuju restoran berada pada jalan utama (protokol). Gaya hidup konsumen DKI Jakarta menginginkan makanan yang praktis (cepat saji) karena rutinitas yang padat, dalam melakukan pembelian pangan konsumen berkunjung ke Restoran GadoGado Boplo.

Hasil penelitian mendukung penelitian terdahulu yang dilakukan oleh Puspitarini (2013) mengenai "pengaruh faktor kebudayaan, sosial, pribadi, dan psikologi terhadap proses keputusan pembelian produk pizza (studi pada pizza hut cabang jalan jenderal sudirman Yogyakarta)", dari hasil penelitian faktor budaya, sosial, pribadi, dan psikologi berpengaruh positif terhadap keputusan pembelian. Hasil ini dapat dilihat pada analisis regresi linier berganda dengan koefesien determinasi $\left(\mathrm{R}^{2}\right)$ dan uji F sebesar 0,742 dari hasil tersebut faktor budaya, sosial, pribadi, dan psikologi secara simultan (bersama-sama) berpengaruh terhadap keputusan pembelian sebesar $74,2 \%$, sedangkan sisanya sebesar $25,8 \%$

dipengaruhi oleh faktor lain yang tidak termasuk dalam penelitian ini, faktor lain yang tidak dimasukan dalam penelitian ini yaitu: jenis produk, bentuk produk, merk, penjual, jumlah produk, waktu pembelian, dan cara pembayaran. Hasil pengujian diperoleh $\mathrm{f}$ hitung 72,008 , dan $\mathrm{f}$ tabel 2,46 $(72,008>2,46)$ dengan nilai signifikansi sebesar 0,000 lebih kecil dari 0,05 $(0,000<0,05)$, maka dapat disimpulkan bahwa "faktor budaya, sosial, pribadi, dan psikologi berpengaruh positif secara simultan (bersamaan) terhadap keputusan pembelian produk pizza pada Pizza Hut Jalan Jenderal Sudirman No.53 Yogyakarta".

\section{KESIMPULAN DAN SARAN}

\section{Kesimpulan}

Berdasarkan Hasil penelitian yang dilakukan maka dapat ditarik beberapa kesimpulan sebagai berikut :

1. Karakteristik responden yang melakukan pembelian di Restoran Gado-Gado Boplo sebagian besar adalah laki-laki sudah menikah pada usia dewasa (25-50 tahun). Pekerjaan yang paling dominan adalah pegawai negeri sipil, sementara itu pendidikan terakhir yang diraih konsumen adalah 
S1. Alasan konsumen membeli produk dari Restoran Gado-Gado Boplo karena kualitas.

2. Faktor budaya berpengaruh terhadap keputusan pembelian konsumen di Restoran Gado-Gado Boplo dengan tingkat signifikansi 0,05.

3. Faktor sosial berpengaruh terhadap keputusan pembelian konsumen di Restoran Gado-Gado Boplo dengan tingkat signifikansi 0,05.

4. Faktor pribadi berpengaruh
terhadap keputusan pembelian
konsumen di Restoran Gado-Gado
Boplo dengan tingkat signifikansi 0,05.

5. Faktor psikologi berpengaruh terhadap keputusan pembelian konsumen di Restoran Gado-gado Boplo dengan tingkat signifikansi 0,05.

6. Faktor budaya, sosial, pribadi, dan psikologi memiliki pengaruh nyata secara statistik terhadap keputusan pembelian konsumen di Restoran GadoGado Boplo dengan tingkat signifikansi 0,05. Uji validitas, reliabilitas, uji asumsi klasik, uji koefesien determinasi $\left(R^{2}\right)$ nyata secara statistik.

\section{Saran}

Berdasarkan kesimpulan diatas dapat diberikan saran sebagai berikut:

1. Bagi Perusahaan

Secara keseluruhan, performa Restoran Gado-Gado Boplo memiliki persepsi yang baik dimata konsumennya. Oleh karena itu, manajemen Restoran Gado-Gado Boplo harus dapat mempertahankan kualitas makanan dan terus memberikan pelayanan yang baik dan dapat memuaskan konsumennya. Sebagai rekomendasi, penelitian ini diharapkan dapat menjadikan acuan untuk dapat mempertahankan unsur beda (diferensiasi), sehingga tetap memotifasi (mendorong) konsumen dimasa mendatang. Berdasarkan telusuran penulis, bahwa responden berkunjung lebih dari satu kali kunjungan. Hal ini perlu dijaga bahkan ditingkatkan guna jaminan kelangsungan usaha Restoran GadoGado Boplo.

2. Bagi Penelitian Selanjutnya

Penulis berharap untuk penelitian selanjutnya dapat mengembangkan penelitian ini dengan meneliti faktor lain yang dapat mempengaruhi proses keputusan pembelian, misalnya keputusan tentang jenis produk, keputusan tentang bentuk produk, keputusan tentang merk, keputusan tentang penjualan, keputusan tentang jumlah produk, keputusan tentang waktu pembelian, dan keputusan tentang cara pembayaran.

\section{DAFTAR PUSTAKA}

Alamsyah, Yuyun. 2009. Antisipasi Krisis Global Bisnis Fast Food A la Indonesia. Jakarta : Elex Media Komputindo

Alma, Buchari. 2007. Pengantar STATISTIKA untuk penelitian pendidikan, sosial,ekonomi, komunikasi, \&Bisnis. Bandung:Alfabeta.

Anonim. Merk dan Presentase Pangsa Pasar Gado-Gado. Halaman :10. 
2014 .www.kulinerart.com. [diunduh pada Desember 2014].

Anonim. 2011. Artikel Rekreasi Restoran Siap Saji.Survei one marketing.

Apriyani, Marlinda dan Fadila Marga. 2013. Pengaruh Faktor Internal Konsumen Terhadap Keputusan Pembelian Sayuran Organik. Jurnal Ilmiah ESAI Volume 7, No.3.Juli 2013. ISSN No.19786034.

Ashari, Purbayu Budi Santoso.2005. Analisis Statistik dengan Microsoft ExCel dan SPSS.Yogyakarta: PT.Raja Grafindo.

Azwar, Saifudin. 2003. Reabilitas dan Validitas. Yogyakarta: Pustaka Pelajar.

Bagyono. 2005. Pengetahuan Dasar Pariwisata dan Perhotelan. Bandung: Alfabeta.

Dinas Pariwisata DKI Jakarta. 2005. Keputusan Menteri Pariwisata, Pos, dan Telekomunikasi (Nomor:73/PW.105/MPPT/1985), dan keputusan Direktorat Jenderal Pariwisata

(Nomor:73/PW/15/U/II/1988), persyaratan penggolongan restoran. Jakarta

Engel, J.F, Roger D.B, dan Paul W.M. 1994. Perilaku Konsumen Jilid 1 dan 2 Jakarta: Binarupa Aksara.

Gado-Godo Boplo. 2013. Profil Perusahaan / Usaha Gado-Gado Boplo Panglima Polim. Jakarta: Restoran Gado-Gado Boplo.

Ghozali, Imam. 2010. Aplikasi Analisis Multivariate dengan Program
SPSS. Semarang: Badan Penerbit UNDIP.

. 2011. Implikasi Aplikasi

Analisis Multivariate dengan Program IBM SPSS 19. Semarang: Badan Penerbit UNDIP.

Gilarso, T. 2004. Pengantar Ilmu Ekonomi Mikro.Yogyakarta: Kanisius.

Gunawan, Puspita M. 2013. Analisis Pengaruh Kepuaasan Terhadap Loyalitas Konsumen Restoran Gado-Gado Boplo (Studi Pada Restoran Gado- Gado

Boplo Kelapa Gading Jakarta Utara)”. [skripsi] Bogor: Institut Pertanian Bogor (IPB) Jurusan Pemasaran.

Hakim. 2005. Menguasai Pasar Mengeruk Untung. Jakarta: Renaisan.

Hawkins, Del I.dan David L.Mothersbough. 2010. Consumer Behavior :Building Marketing Strategy.New York:Mc-Graw Hill.

Hidayat, S. 2002. Analisis Permintaan Konsumen Terhadap Produk Daging Sapi Segar di Pasar Swalayan Hero. [skripsi] Bogor: Institut Pertanian Bogor (IPB) Fakultas Peternakan.

Kotler, Philip. 2000. Dasar-dasar Pemasaran. Jakarta: Intermedia.

2005. Manajemen Pemasaran. Jilid 1. Jakarta: PT Indeks.

Kotler, Philip dan Gary Amstrong. 2012. Principles of Marketing. New Jersey: Person Education.

Kotler, Philip dan Kevin Lane Keller. 2009. Manajemen pemasaran, Edisi 12 
dan 13 Jilid 1 dan 2. Jakarta: PT. Indeks Indonesia.

Leon G.Schiffman dan Leslie Lazar Kanuk. 2002. Perilaku Konsumen. Jakarta: PT Gramedia.

Mahendra, Giri. 2014. Pengujian Hipotesis dengan Uji Koefesien. diunduh dari

http://girimahendera.blogspot.com /2015/05/pengujian-hipotesisujikoefesien.html [diakses pada tanggal 22 Desember 2014].

Mangkunegara, Anwar P. 2002. Perilaku Konsumen Edisi Revisi. Bandung: PT Refika Aditama.

Mukhtar. 2004. Usaha Pengelolaan Dapur Dalam Meningkatkan Kualitas Makanan Pada Hotel. Medan: [Skripsi] Program Studi Pariwisata. Fakultas Sastra, USU.

Nielsen. 2008. Majalah Appetite Journey, 1/V/Okt 2008. Resipitory.upi.edu [diakses pada tanggal 9 November 2014].

Priyanto, Dwi. 2008. Mandiri Belajar SPSS (Statistical Product and Service Solution) untuk analisis data dan uji statistik. Yogyakarta: Mediakom.

Puspitarini, Dian. 2013. Pengaruh Faktor Kebudayaan, Sosial, Pribadi, dan Psikologi Terhadap Proses Keputusan Pembelian Produk Pizza (Studi Pada

Pizza Hut Cabang Jalan Jenderal Sudirman No.53 Yogyakarta)”. [Skripsi] Yogyakarta: Universitas Negeri Yogyakarta (UNY) Fakultas Ekonomi.
Santoso, Singgih. 2014. Statistik Parametrik. PT.Elex Media Komputindo.

Sarjono, Haryadi dan Julianita Winda. 2011. SPSS VS LISREL Sebuah Pengantar,Aplikasi untuk Riset. Jakarta: Salemba Empat.

Setianingrum. 2003. Analisis FaktorFaktor yang Mempengaruhi Perilaku

Konsumen Dalam Pengambilan Keputusan Pembelian Pisang "Sunpride”. [Skripsi] Bogor: Institit Pertanian Bogor (IPB) Fakultas Pertanian.

Sheth, Jagdish dan Naresh Maholtra. Global Consumer Culture. Encyclopedia of international marketing. (halaman;8-9). 2000

Http:www.uwyo.udu/sustainable/recentres earch/docs/global $\% 20$ consumer $\%$ 20\%culture $\% 20$ arnould.pdf [diakses pada 25 Februari 2015].

Siregar, Syofian. 2014. Statistika Deskriptif untuk penelitian dilengkapi Perhitungan Manual dan Aplikasi SPSS versi 17. Jakarta: Rajawali Pers.

Simamora, Bilson. 2004. Panduan Riset Perilaku Konsumen, cetakan kedua. Jakarta: Gramedia Pustaka Utama.

Soekadijo, R.G. 2000. Anatomi Pariwisata: Memahami Pariwisata Sebagai

"Systemic Lingkage".Jakarta: PT. Gramedia Pustaka Utama.

Soekartawi, A.1993. Prinsip Dasar Ekonomi Pertanian; Teori dan Aplikasinya Edisi Ke-2 Jakarta: PT. Raja Grafindo Persada.

Sugiyono. 2012. Metode Penelitian Bisnis: Pendekatan Kuantitatif, Kualitatif, 
Research dan Development. Bandung: Alfabeta.

Sumarwan, U. 2004. Perilaku Konsumen: Teori dan Penerapannya dalam Pemasaran. Bogor: Ghalia Indonesia.

Suhardjo, Harper L. J, Deaton B. J, dan Driskel J. A. 1997. Pangan, Gizi dan Pertanian. Jakarta: Universitas Indonesia.

Sukirno, Sadono. 2005. Mikro Ekonomi Teori Pengantar edisi ketiga. Jakarta: PT.Rajagrafindo Persada.

Suliyanto. 2009. Metode Riset Bisnis. Yogyakarta: Andi.

Suliyanto. 2005. Analisis Data Dalam Aplikasi Pemasaran. Bogor: PT. Ghalia Indonesia.

Suyadi, Prawirosentono. 2002. Pengantar Bisnis Modern. Jakarta: Bumi Aksara.

Sutisna. 2001. Perilaku Konsumen dan Komunikasi Pemasaran. Bandung: PT. Rosdakarya.

Sutrisno, Hadi. 2000. Metodologi Research. Yogyakarta: Andi.

Tjiptono, Fandy. 2001. Strategi Pemasaran. Yogyakarata: Andi.

Uma, Sekaran. 2006. Metodologi Penelitian Untuk Bisnis. Jakarta: Salemba.

Umar, Husein. 2002. Metode Riset Bisnis. Jakarta: PT. Gramedia Pustaka Utama.

Umar, Husein. 2003. Riset Pemasaran dan Perilaku Konsumen. Jakarta:
PT.Gramedia Pustaka Utama anggota IKAPI.

Umar, Husein. 2011. Metode Penelitian Untuk Skripsi dan Tesis. Jakarta: PT.Raja Grafindo Persada.

Umar, Husein. 2002. Metode Riset Bisnis Dilengkapi contoh proposal dan Hasil Riset Bidang Manajemen dan Akuntansi. Jakarta: PT.Gramedia Pustaka Utama anggota IKAPI.

Widarjono, Agus. 2007. Ekonometrika Teori dan Aplikasi untuk Ekonomi dan Bisnis, Edisi kedua cetakan kesatu. Yogyakarta: Ekonesia Fakultas Ekonomi UII.

Zulfikar, Muhammad Wimman. 2011. "Analisis Pengaruh Bauran Pemasaran Terhadap Keputusan Pembelian. (Studi Kasus: Oase Batik Pekalongan) [Skripsi] Semarang : Universitas Dipenogoro (UNDIP). 